This manuscript is a non-peer reviewed EarthArXiv pre-print. A DOI for the peer-reviewed version will be provided once the manuscript has been accepted. We encourage feedback to the authors.

\title{
1 Catchment vegetation and erosion controls soil carbon cycling in south-eastern Australia during the last two Glacial-Interglacial cycles
}

Francke, A. ${ }^{1-3^{*}}$, Dosseto, A. ${ }^{1,2,4}$, Forbes, M. ${ }^{4,5}$, Cadd, H. ${ }^{4,6}$, Short, J. ${ }^{7,8}$, Sherborne-Higgins, B. ${ }^{2,4}$, Constantine, M. ${ }^{6}$, Tyler, J. ${ }^{3}$, Tibby, J. ${ }^{7,8}$, Marx, S. ${ }^{2,4}$, Dodson, J. ${ }^{9}$, Mooney, S. ${ }^{6}$, and Cohen, T.J. ${ }^{2,4}$

${ }^{1}$ Wollongong Isotope Geochronology Laboratory, School of Earth, Atmospheric and Life Sciences, 10 University of Wollongong, Australia

$11{ }^{2}$ GeoQuEST Research Centre, School of Earth, Atmospheric and Life Sciences, University of

12 Wollongong, Australia

$13{ }^{3}$ Department of Earth Sciences, University of Adelaide, Australia

$14{ }^{4}$ ARC Centre of Excellence for Biodiversity and Heritage, School of Earth, Atmospheric and Life

15 Sciences, University of Wollongong, Australia

$16{ }^{5}$ KCB Australasia pyt Itd, Brisbane, Australia

${ }^{6}$ School of Biological Earth and Environmental Sciences, University of New South Wales, Australia

${ }^{7}$ Department of Geography, Environment and Population, University of Adelaide, Australia

${ }^{8}$ Sprigg Geobiology Centre, University of Adelaide, Australia

${ }^{9}$ Institute for Earth Environment, Chinese Academy of Science, Xi'an, Shaanxi, China

* corresponding author: alexander.francke@adelaide.edu.au

\section{Abstract}

The vegetation structure in vast semi-arid to temperate continental land masses, particularly in

Australia, play a considerable role in global terrestrial carbon dioxide sequestration. However,

whether soil-carbon is a net atmospheric carbon source or sink remains contentious, introducing

large uncertainties on long-term storage of vegetation-sequestered carbon dioxide. We investigate

the interplay between catchment erosion (quantified by means of uranium isotopes), vegetation

30 (pollen), catchment carbon cycling, wetland response (diatoms), and lake carbon accumulation on

31 glacial-interglacial timescales in south-eastern Australia during the last (133.5 ka to $107.6 \mathrm{ka}$ ) and

32 current (17.8 cal ka BP to present day) glacial-interglacial cycle. The analyses are applied to the 
This manuscript is a non-peer reviewed EarthArXiv pre-print. A DOI for the peer-reviewed version will be provided once the manuscript has been accepted. We encourage feedback to the authors.

33 sediments of Lake Couridjah, located in the Sydney Basin, and are supported by uranium isotope and

34 carbon contents of a ridge-crest soil pit from the vicinity of the lake.

35 Statistical analyses reveal robust phase-relationships between catchment erosion, vegetation 36 composition, and carbon cycling during both glacial-interglacial periods. The data implies that

37 vegetation structure, and not the amount of rainfall, had a more direct control on catchment erosion,

38 and, thus, on SOC erosion in the catchment. Overall wetter and warmer (peak interglacial) conditions

39 promoted the expansion of a canopy and mid-storey cover and reduced catchment erosion, while

40 simultaneously increasing SOC storage, catchment and lake primary productivity, and lake carbon

41 storage. The results may imply increased (reduced) terrestrial carbon dioxide sequestration in overall

42 warmer and wetter (colder and drier) climates.

\section{1. Introduction}

44 Soil organic carbon (SOC) makes up to $80 \%$ of the terrestrial carbon pool (Doetterl et al., 2016).

45 However, there is little information on the fate of SOC during soil erosion, introducing large 46 uncertainties into national carbon flux estimates, Earth System Models (ESM), and General

47 Circulation Models (GCM, Doetterl et al., 2016; Lugato et al., 2018; Francke et al., 2020a). Reanalysis

48 of national greenhouse gas emissions in Australia, for example, has suggested that not considering

49 cropland soil erosion overestimated the nation's net carbon flux into the atmosphere by $40 \%$

50 (Chappell et al., 2015), explained by SOC lost by erosion and subsequently buried in sedimentary sinks

51 rather than being re-oxidised (Chappell et al., 2015). This has led to an ongoing debate as to whether

52 soil-carbon is a net atmospheric source or sink in the global carbon cycle (Chappell et al., 2015;

53 Doetterl et al., 2016; Lugato et al., 2018), primarily related to gaps in our understanding of how lateral

54 soil fluxes connect terrestrial and aquatic carbon cycling (Luo et al., 2016). These uncertainties

55 become greater when constraining carbon fluxes on geological timescales, where "land use 
This manuscript is a non-peer reviewed EarthArXiv pre-print. A DOI for the peer-reviewed version will be provided once the manuscript has been accepted. We encourage feedback to the authors.

harmonization" (LUH) models integrated in GCMs or ESMs are based on landscape models such as

57 HYDE (Klein Goldewijk et al., 2017) or KK10 (Kaplan et al., 2009). Direct vegetation modelling, which

58 accounts for different pollen production and accumulation processes (e.g. LOVE, REVEALS, Sugita, 2007a; Sugita, 2007b; Trondman et al., 2015; Li et al., 2020) combined with quantitative estimates about catchment erosion, landscape change, and carbon cycling over time are still challenging to obtain (Francke et al., 2020a). Detailed multiproxy studies on erosion, vegetation, climate, and terrestrial-aquatic carbon cycling on geological timescales are one of the few approaches that can investigate these interactions simultaneously.

The arid, semi-arid, and temperate regions of the Southern Hemisphere are particularly important for understanding carbon fluxes, since wetter climates can significantly increase terrestrial biomass production in these regions, rapidly turning vast continental areas into globally significant carbon sinks (Haverd et al., 2013). This was demonstrated in Australia during the 2011 strong La-Niña event, when large areas of the continental interior experienced substantial 'greening', and a significant

69 increase in global carbon uptake (Poulter et al., 2014; Haverd et al., 2016). Australia is also characterised by many ephemeral wetlands, and the wetting and drying of these systems has the potential to significantly affect carbon storage over various timescales.

72 Here we report an investigation of the catchment-wide dynamics of SOC and erosion at Lake

73 Couridjah, part of the Thirlmere Lakes, located in temperate Australia, south-west of Sydney in the

74 Sydney Basin (Fig. 1). Lake Couridjah provides an outstanding natural laboratory to study catchment75 wide carbon cycling due to its small catchment $\left(<5 \mathrm{~km}^{2}\right)$, allowing catchment changes to be readily 76 transmitted to lake sediments. In addition, its temperate climate is characteristic of wide parts of south-eastern (SE) Australia, its uniform sandstone lithology is widespread across Australia, and its location within a World Heritage Listed National Park that has preserved intact its dry sclerophyll 
This manuscript is a non-peer reviewed EarthArXiv pre-print. A DOI for the peer-reviewed version will be provided once the manuscript has been accepted. We encourage feedback to the authors.

lacustrine sediments span at least the last and current glacial-interglacial cycle (Forbes et al., 2021),

81 allowing examination of the interplay between vegetation, erosion, SOC mobility, and wetland

82 response under various climatic conditions.

83 We used a multi-proxy approach, studying soil and sedimentary total organic carbon, as well as

84 palaeoecological data (pollen, charcoal, diatoms) to consider catchment-wide SOC cycling. We overcome current analytical limitations to quantify catchment-wide erosion in fine-grained

86 depositional archives by using the uranium isotope compositions $\left({ }^{234} \mathrm{U}\right.$ and $\left.{ }^{238} \mathrm{U}\right)$ of fine-grained

87 detrital matter to infer palaeo-sediment residence times. This is defined as the time elapsed between

88 comminution of bedrock in the weathering horizon and the final deposition in the sedimentary sink

89 (Fig. 2). The conceptual model introduced by DePaolo et al. (2006) is based on $\alpha$-recoil induced

90 depletion of the intermediate radioactive nuclide ${ }^{234} \mathrm{Th}$ from fine-grained detritus in the weathering

91 profile, during transportation, temporary storage, and after final deposition (reviewed in Dosseto

92 and Schaller, 2016; Francke et al., 2020a). Recent research has further substantiated the approach

93 via detailed assessments of uranium mobility before and after final deposition (Martin et al., 2019;

94 Francke et al., 2020b), and by comprehensive statistical analyses of lithologic, weathering, climatic, 95 and morphologic controls on $\left({ }^{234} \mathrm{U} /{ }^{238} \mathrm{U}\right.$ ) activity ratios in modern stream sediments (Thollon et al., 96 2020).

\section{2. Material and Methods}

\section{$98 \quad 2.1$ Regional Setting}

99 Lake Couridjah is part of the Thirlmere Lake system ( $\left.34^{\circ} 13^{\prime} \mathrm{S} ; 150^{\circ} 13^{\prime} \mathrm{E}\right)$, which consists of five lakes 100 (total basin area of $4.85 \mathrm{~km}^{2}$ ) located approximately $100 \mathrm{~km}$ south-west of Sydney (Australia) at 300 $101 \mathrm{~m}$ above sea level (Fig. 1). The Thirlmere Lakes are located within an abandoned, Cenozoic meandering river valley with a distinctive U-shaped arrangement (Timms, 1992). 
This manuscript is a non-peer reviewed EarthArXiv pre-print. A DOI for the peer-reviewed version will be provided once the manuscript has been accepted. We encourage feedback to the authors.

103 The morphology of the Thirlmere Lakes catchment is characterised by steep Hawkesbury Sandstone 104 scarps ( $20-30 \mathrm{~m}$ in height) grading to plateau surfaces $\sim 50$ to $75 \mathrm{~m}$ above the lake floor. Small 105 Pleistocene alluvial fans separate the five lakes and form gently inclined slopes to the valley floor. 106 Readily erodible shales of the Wianamatta Group, capping the Hawkesbury Sandstone, have limited 107 exposure in the Thirlmere catchment today (Forbes et al., 2021).

108 The present day vegetation at Thirlmere has previously been described by Black et al. (2006), Rose 109 and Martin (2007) and Forbes et al. (2021). A detailed survey of the contemporary vegetation in the 110 vicinity of Lake Couridjah shows the catchment is presently dominated by an open sclerophyll forest 111 (Forbes et al., 2021, Fig. 1 and Supplementary information).

112 Average summer and winter temperatures at Thirlmere are $29^{\circ} \mathrm{C}$ and $10^{\circ} \mathrm{C}$, respectively (Bureau of 113 Meteorology, 2021). Annual evaporation (1400 to $1600 \mathrm{~mm} \cdot \mathrm{yr}^{-1}$ ) exceeds annual precipitation (800 $114 \mathrm{~mm}$, Bureau of Meteorology, 2021). Precipitation is distributed evenly across seasons, with summer 115 precipitation associated with north-easterly weather systems (tropical derived East Coast Lows and 116 easterly troughs, and onshore anticyclonic ridges) and winter precipitation with north-westerly 117 moving air-masses. This seasonal pattern results from the system's location at the latitudinal 118 transition zone between the mid-latitude westerly and tropical-influenced synoptic-weather 119 systems. Variations in annual and decadal rainfall amounts in SE Australia are linked to interactions 120 between El-Niño Southern Oscillation (ENSO), the Pacific Decadal Oscillation (PDO) variability, the 121 Southern Annual Mode (SAM), and the Indian Ocean Dipole (IOD), and are mainly expressed by 122 variations in winter rainfall (van Dijk et al., 2013). The Thirlmere Lakes are presently characterised as 123 ephemeral, however, water depths up to $5 \mathrm{~m}$ were reported during the 1950 - 1960s (Horsfall et al., 124 1988). The lake levels closely follow reconstructed water levels of other lakes in SE Australia during 125 the last century (Short et al., 2020), implying the Thirlmere Lakes are highly sensitive to regional 126 climate forcing. 
This manuscript is a non-peer reviewed EarthArXiv pre-print. A DOI for the peer-reviewed version will be provided once the manuscript has been accepted. We encourage feedback to the authors.

\subsection{Palaeolimnology and chronostratigraphy}

128 A comprehensive, multidisciplinary palaeolimnological and chronostratigraphic study has previously

129 been carried out on a $6.8 \mathrm{~m}$ long sediment core (LC2) from the central part of Lake Couridjah. 130 Sedimentary (grain size, mineralogy), geochemical (major inorganic and organic element 131 geochemistry, carbon and nitrogen stable isotopes, ${ }^{13}$ C-Nuclear Magnetic Resonance), 132 palaeoecological (pollen, diatoms, charcoal, chironomids) and chronostratigraphic (radiocarbon $\left[{ }^{14} \mathrm{C}\right]$ 133 and optically stimulated luminescence [OSL]) data are presented in Forbes et al. (2021). In summary, 134 chronostratigraphic ( $13{ }^{14} \mathrm{C}$ and nine OSL) and sedimentary data indicated the lower part of LC2 135 covers the time intervals between $\sim 133.5 \mathrm{ka}$ and $\sim 107.6 \mathrm{ka}$ ( $6.8 \mathrm{~m}$ to $3.2 \mathrm{~m}$ dated by means of single 136 grain optically stimulated luminescence [OSL] reported as kilo annum, ka), and the upper part the 137 time interval between $\sim 17.8 \mathrm{cal} \mathrm{ka} B P$ and present day $(3.2 \mathrm{~m}$ to $0 \mathrm{~m}$ dated by means of AMS 138 radiocarbon dating and calibrated using the SHCal20, and reported as calibrated years before 139 present, cal. ka BP, Fig. S1). A major hiatus was identified at $3.2 \mathrm{~m}$ sediment depth, between these 140 two intervals (Forbes et al., 2021). Sediments attributed to warmer and wetter intervals are 141 characterised by high sedimentary organic matter (OM) contents and the sediments are classified as 142 peat (for the Holocene) and organic silty clay (between $130 \mathrm{ka}$ and $115 \mathrm{ka}$, broadly corresponding to 143 marine isotope stage (MIS) 5e, Fig. S1). Interstadial (115 ka to $107.6 \mathrm{ka}$, broadly corresponding to 144 MIS5d) and glacial (133.5 ka to 130 ka broadly corresponding to the penultimate glacial, and 17.8 cal 145 ka BP to 11.6 cal ka BP corresponding to the Late Glacial) sediments show lower OM contents and 146 were characterized as organic silty clay, silty clay, and sandy clay (Forbes et al., 2021).

\section{$147 \quad 2.3$ Methods}

148 X-ray fluorescence (XRF) core scanning, organic carbon content, diatom, charcoal, and pollen data and their methods have been reported in Forbes et al. (2021). Previously unpublished data presented in this study comprise uranium isotope analyses on LC2 and bedrock samples (outcrop and drill hole 
This manuscript is a non-peer reviewed EarthArXiv pre-print. A DOI for the peer-reviewed version will be provided once the manuscript has been accepted. We encourage feedback to the authors.

151

samples), as well as uranium isotopes, organic carbon content, and major element concentrations (titanium and potassium) on a $50 \mathrm{~cm}$ soil pit (Werri Berri Ridge Crest 1 - WBRC1) located on the ridge crest of neighbouring Lake Werri Berri. Six $5 \mathrm{~cm}$ thick samples were taken consecutively from the upper $35 \mathrm{~cm}$, with a final sample taken at $50 \mathrm{~cm}$ (the soil-saprolite interface). Major element concentrations were analysed using standard techniques (see Supplement for more details).

Uranium isotope analysis of six soil, 31 sediment (1 cm thick, core LC2), and bedrock (four outcrop and one drill core samples) was carried out at the Wollongong Isotope Geochronology Laboratory, University of Wollongong. All soil and sediment samples were sieved to $63 \mu \mathrm{m}$, and the fine fraction was used for further analyses. Sonication-supported sequential leaching to remove non-detrital matter from the bulk soil and sediment sample and hydrofluoric-nitric and aqua regia sample dissolution followed the method described in Francke et al. (2018). Bedrock samples were crushed and powdered and the same procedure for sample dissolution as described for the soil and sediment samples was applied. Uranium was separated from the sample matrix using the automated chromatography system prepFAST-MC ${ }^{\mathrm{TM}}$ (Elemental Scientific) equipped with a company (Elemental Scientific) provided column ThU1 - 0500. The samples were refluxed in $7 \mathrm{M} \mathrm{HNO}_{3}$ prior to chromatography, and Th and $\mathrm{U}$ were eluted in IQ $6 \mathrm{M} \mathrm{HCl}$ and $18.2 \mathrm{M} \Omega \mathrm{H}_{2} \mathrm{O}$. A ThermoFisher (Bremen, Germany) Neptune multi-collector inductively coupled plasma mass spectrometer (MC ICP-MS) was used for uranium isotope analyses. Details on mass spectrometry analysis and on analytical accuracy and precisions are reported in the Supplement. A subset of chemically treated (sequential leaching applied) lake core samples were analysed for surface area and roughness on a Quantachrome Autosorb iQ (Table S3) using the method described in Francke et al. (2018) and in the Supplement.

\subsection{Calculations}

To calculate palaeo-sediment residence times, we used equations developed by Martin et al. (2019) and Francke et al. (2020b) to account for preferential leaching of ${ }^{234} \mathrm{U}$ before and after deposition 
This manuscript is a non-peer reviewed EarthArXiv pre-print. A DOI for the peer-reviewed version will be provided once the manuscript has been accepted. We encourage feedback to the authors.

175 separately. Preferential leaching can promote lower $\left({ }^{234} \mathrm{U} /{ }^{238} \mathrm{U}\right)$ activity ratios in detrital grains that

176 is not related to recoil-loss of ${ }^{234} \mathrm{Th}$. Different scenarios for pre- and post-depositional preferential

177 leaching of ${ }^{234} \mathrm{U}$ and different scenarios for (reduced) loss of ${ }^{234} \mathrm{Th}$ by recoil after final deposition were

178 tested (see Supplement). Palaeo-sediment residences times were calculated for LC2 using Monte

179 Carlo simulations (10,000 simulations) to account for uncertainties in our input parameters using an

180 R64 script (available upon request to the authors).

181 Partial Least Square Regression (PLSR) analysis was performed on previously published pollen relative

182 abundance data (as predictor variables) and palaeo-sediment residence times (as response variables)

183 to consider relationships between vegetation change and catchment erosion. Aquatic and semi-

184 aquatic pollen taxa (such as Cyperaceae) were excluded from the total pollen sum and relative

185 abundances were re-calculated for terrestrial taxa (Forbes et al., 2021, supplement).

186 Chenopodiaceae pollen was excluded from the terrestrial pollen sum as it occurred at very low

187 percentages, likely indicating it is derived by windblown transportation from outside the catchment

188 (Dodson, 1983; Williams et al., 2006). Re-calculated relative abundances of Myrtaceae +

189 Casuarinaceae, Acacia (genus), Asteraceae (Asteroideae or Tubuliflorae), and Poaceae and palaeo-

190 sediment residence times were normalized ( mean $=0$, standard deviation $=1$ ) prior to PLSR analyses.

191 PLSR analyses was undertaken for current and last glacial-interglacial sediments separately.

192 3. Results

\section{$193 \quad 3.1$ Modern catchment data}

194 Uranium isotopes of samples from unweathered Hawkesbury Sandstone from a core penetrating 21

$195 \mathrm{~m}$ into the bedrock reveal $\left({ }^{234} \mathrm{U} /{ }^{238} \mathrm{U}\right)$ activity ratios above 'secular equilibrium' $\left(\left({ }^{234} \mathrm{U} /{ }^{238} \mathrm{U}\right)\right.$ activity

196 ratios $=1$ ). Bedrock collected from outcrops in the Thirlmere catchment show significant depletion

197 in ${ }^{234} \mathrm{U}$ (Fig. 3). Uranium isotope analyses of the $50 \mathrm{~cm}$ deep soil pit WBRC1 located on the ridge crest 
This manuscript is a non-peer reviewed EarthArXiv pre-print. A DOI for the peer-reviewed version will be provided once the manuscript has been accepted. We encourage feedback to the authors.

198 of neighbouring Lake Werri Berri yielded $\left({ }^{234} \mathrm{U} /{ }^{238} \mathrm{U}\right)$ activity ratios between 0.856 and 0.892 , thus

199 showing expected recoil-induced depletion of ${ }^{234} \mathrm{U}$ in fine-grained $(<63 \mu \mathrm{m})$ detrital matter. The 200 activity ratios increased with greater soil depth (Fig. 3).

$201 \mathrm{~K} / \mathrm{Ti}$ ratios of bulk-detrital soil samples between $0 \mathrm{~cm}$ and $35 \mathrm{~cm}$ depth in WBRC1 are low and steady $202(\mathrm{~K} / \mathrm{Ti}=0.4$ to 0.5 , Fig. 3). High ratios occur in the sample taken at $50 \mathrm{~cm}$ depth and in the underlying 203 saprolite $(\mathrm{K} / \mathrm{Ti}=2.2)$. SOC, as inferred from WBRC1 soil-TOC, is between $\sim 1$ and $3.9 \%$, with values $204>1.5 \%$ only found in the upper $20 \mathrm{~cm}$. The OM-rich topsoil layer overlayed a thick sandy horizon with 205 poor vertical soil stratification, classifying WBRC1 as skeletal soil.

\section{$206 \quad 3.2$ The last and current glacial-interglacial cycle}

207 Monte-Carlo modelled palaeo-sediment residence times (i.e. time elapsed between comminution 208 and final deposition reported in kyr, Fig. 2) ranged from 15 to 70 kyrs in sediments deposited between $209133 \mathrm{ka}$ to $130 \mathrm{ka}$ (broadly equivalent to MIS 6), between $115 \mathrm{ka}$ and $107.6 \mathrm{ka}$ (broadly equivalent to 210 MIS5d), and between $17.8 \mathrm{cal}$ ka BP and $11.6 \mathrm{cal}$ ka BP (Late Glacial), respectively. Longer residence 211 times, between 70 kyrs and 124 kyrs, were evident between depositional ages of $130 \mathrm{ka}$ and $115 \mathrm{ka}$ 212 (broadly equivalent to MIS5e), between 17.8 cal ka BP and 16 cal ka BP, and during the Holocene 213 (11.6 ka to present day).

214 Terrestrial pollen taxa abundance indicate Lake Couridjah's catchment vegetation was composed of 215 sclerophyll trees and shrubs (Myrtaceae + Casuarinaceae between 44\% and 86\%) during both the last 216 (133.5 ka to $107.6 \mathrm{ka}$ ) and current (17.8 cal ka BP to present day) glacial-interglacial (Fig. 4). The 217 pollen of Acacia (0.6\% to 3.5\%) genus occurs at low abundance during both climate cycles. Herb and 218 grassland vegetation cover, comprising of Asteraceae (Asteroideae or Tubuliflorae, 1\% to 48\%) and 219 Poaceae (2.5\% to $22.5 \%$ ) contributed substantially to the vegetation composition in the Thirlmere 220 catchment during both glacial-interglacial cycles. Broadly, higher proportions of arboreal taxa 221 (Myrtaceae + Casuarinaceae and-or Acacia) and lower proportions of understorey taxa (Asteraceae 
This manuscript is a non-peer reviewed EarthArXiv pre-print. A DOI for the peer-reviewed version will be provided once the manuscript has been accepted. We encourage feedback to the authors. and Poaceae) occurred during warmer and wetter intervals (130 ka and $115 \mathrm{ka}$ and during Holocene,

223 Fig. 4). Peaks in macroscopic charcoal area $\left(\mathrm{mm}^{2} / \mathrm{cm}^{3} / \mathrm{yr}\right)$ between $130 \mathrm{ka}$ and $115 \mathrm{ka}$ and during Last

224 Glacial corresponded to declines in Myrtaceae + Casuarinaceae and-or Acacia (Fig. 4). Stable 225 Polycyclic Aromatic Carbon (SPAC) abundance was higher between $130 \mathrm{ka}$ and $115 \mathrm{ka}, 106 \mathrm{ka}$ and $226103 \mathrm{ka}$, and during the Holocene (Fig. 4).

227 PLSR analyses of terrestrial pollen taxa (Myrtaceae + Casuarinaceae, Acacia, Asteraceae, Poaceae) 228 and palaeo-sediment residence times were preformed separately for the last and current glacial229 interglacial cycle (Fig. 5). The statistical analysis reveals strong positive loading on predictor axis 1 for 230 Myrtaceae + Casuarinaceae and Acacia during the last glacial-interglacial (Fig. 5). Only Myrtaceae + 231 Casuarinaceae shows strong positive loadings on predictor axis 1 for the current glacial-interglacial 232 (between 17.8 cal yr BP and present). Asteraceae and Poaceae have strong negative loadings on PLSR 233 predictor axis 1 in the last glacial-interglacial (133 ka to $107 \mathrm{ka}$ ). Strong negative loadings for 234 Asteraceae and Poaceae and weak negative loadings for Acacia occur on PLSR predictor axis 1 for the 235 current glacial-interglacial. PLSR predictor axis 1 is consequently indicative for the catchment 236 vegetation structure. Monte-Carlo modelled palaeo-sediment residence times showed strong 237 positive loadings on response axis 1 for both the last and the current glacial-interglacial cycle (Fig. 5). 238 A significant correlation is identified between the PLSR scores from predictor axis 1 (combined results 239 for the last and current glacial-interglacial cycle) and catchment sediment residence times (Fig. 7A, $\left.240 \mathrm{R}^{2}=0.48, \mathrm{p}<0.005\right)$. No significant correlation is observed between $\mathrm{K} / \mathrm{Ti}$ and palaeo-sediment 241 residence times (Fig. 7G, $\mathrm{R}^{2}=0.19, \mathrm{p}>0.005$ ), but a significant negative correlation is found between $242 \mathrm{~K} / \mathrm{Ti}$ and Myrtaceae + Casuarinaceae abundance (Fig. 7H, $\left.\mathrm{R}^{2}=0.52, \mathrm{p}<0.005\right)$.

243 The accumulation of organic carbon in the sediments of Lake Couridjah, as inferred from TOC acc, $_{\text {, }}$ 244 resembles the variability recorded in palaeo-sediment residence times (Fig. 6). Overall higher TOC $\mathrm{Cacc}$ 245 occured in both peak interglacials (130 ka to $115 \mathrm{ka}$, and the Holocene). Somewhat higher 
This manuscript is a non-peer reviewed EarthArXiv pre-print. A DOI for the peer-reviewed version will be provided once the manuscript has been accepted. We encourage feedback to the authors.

246 abundances of aerophilic + epiphytic diatoms (up to 77\%) were recorded between $133.5 \mathrm{ka}$ and 115

247 ka and during the Holocene (Fig. 6), while lower abundance (less than 45\%) occurred between 115

$248 \mathrm{ka}$ and $107.6 \mathrm{ka}$, when planktonic diatoms were abundant. Planktonic diatom abundance was low 249 and variable between $133.5 \mathrm{ka}$ and $115 \mathrm{ka}$, low and steady during the Last Glacial, and almost absent 250 during the Holocene (Fig. 6).

\section{4. Discussion}

\subsection{Modern catchment data}

253 Disequilibrium of ${ }^{238} \mathrm{U}-{ }^{234} \mathrm{U}$ in bedrock older than $1 \mathrm{Ma}$, as recorded in our catchment data, has 254 previously been attributed to deep weathering and fracturing. Uranium- $234 / 238 \mathrm{U}$ activity ratios 255 greater than 1 can be driven by (a) the isotopic ratio of uranium rich mineral coatings and-or 256 secondary sandstone cement, or (b) by recoil from either of these sources into the mineral grain 257 (Reynolds et al., 2003; Dosseto and Schaller, 2016). Activity ratios < 1 detected in the rock samples 258 collected in outcrops imply these rocks have undergone substantial weathering. Uncertainties about 259 the initial bedrock $\left({ }^{234} \mathrm{U} /{ }^{238} \mathrm{U}\right)$ activity ratios can influence the calculated catchment sediment 260 residence times as discussed in detail in the Supplement.

261 In soil pit WBRC1, higher $\left({ }^{234} \mathrm{U} /{ }^{238} \mathrm{U}\right)$ activity ratios occur at greater soil depth, close to the bedrock262 weathering horizon interface, and lower $\left({ }^{234} \mathrm{U} /{ }^{238} \mathrm{U}\right)$ activity ratios occur in topsoil layer (Fig. 3). This 263 is a common feature across SE Australia (e.g. Dosseto et al., 2008; Suresh et al., 2013), attributed to 264 the downward migration of the bedrock to weathering horizon interface over time. It implies deeper 265 erosion predominately mobilises detrital matter with high $\left({ }^{234} \mathrm{U} /{ }^{238} \mathrm{U}\right)$ activity ratios. Uranium$266234 / 238 \mathrm{U}$ activity ratios and palaeo-sediment residence times in sedimentary archives have thus been used as proxy for erosion processes and erosion depth (shallower versus deeper erosion) in settings 
This manuscript is a non-peer reviewed EarthArXiv pre-print. A DOI for the peer-reviewed version will be provided once the manuscript has been accepted. We encourage feedback to the authors.

269 Rothacker et al., 2018; Francke et al., 2019). Although temporary storage of sediments $>10,000$ years

270 may be expected for the alluvial fans separating the Thirlmere lakes, these features primarily consist

271 of sand-sized material (Forbes et al., 2021). Therefore, we infer detrital matter $<63 \mu \mathrm{m}$, targeted

272 during uranium isotope analyses, is rapidly transported to Lake Couridjah. In the Thirlmere

273 catchment, detrital matter with lower $\left({ }^{234} \mathrm{U} /{ }^{238} \mathrm{U}\right)$ activity ratios might be stored for extended periods

274 in skeletal soils on the gently inclining slopes closer to the lake and on top of the ridge crests, and

275 may be mobilised by shallower and slower erosion. Detrital matter with higher $\left({ }^{234} \mathrm{U} /{ }^{238} \mathrm{U}\right)$ activity

276 ratios might be mobilised by somewhat deeper and faster erosion of thin skeletal soils formed on

277 steeper slopes in vicinity of the scarps (Fig. 1). An additional contributor to erosional processes in the

278 Thirlmere catchment may be mass wasting (rockfalls, topples) as evident in the Thirlmere catchment

279 today, and as described elsewhere in the Sydney Basin (Tomkins et al., 2004). However, boulders and

280 blocks mobilised during rockfalls would not contribute to the lake sediment's $\left({ }^{234} \mathrm{U} /{ }^{238} \mathrm{U}\right)$ activity ratio

281 budget. The majority of detritus delivered to Lake Couridjah likely originates from scarps and soils

282 below the ridge crests, with the steeper slopes being covered by thinner soils (compared to those on

283 the ridge crests), which are also more prone to deeper erosion.

284 TOC and trace metal isotope geochemistry of the soil pit WBRC1 yield a strong covariance of soil 285 depth versus time of detrital matter storage and SOC storage (Fig. 3, see Fig. S3 for correlation 286 coefficients). The data implies shallower erosion mobilises the SOC rich topsoil layer (high TOC) and 287 detrital matter stored in the soil and weathering horizons for an extended time (low $\left({ }^{234} \mathrm{U} /{ }^{238} \mathrm{U}\right.$ ) 288 activity ratios). Deeper erosion would mobilise SOC poor horizons (low TOC) and detrital matter 289 stored in the soil or weathering horizon for shorter time (with higher $\left({ }^{234} \mathrm{U} /{ }^{238} \mathrm{U}\right)$ activity ratios).

290 Erosion depth would have no impact on the mobilised material's degree of chemical alteration, since 291 there is no depth-dependent variability in $\mathrm{K} / \mathrm{Ti}$, unless saprolite is mobilised by deep erosion (Fig. 3). 
This manuscript is a non-peer reviewed EarthArXiv pre-print. A DOI for the peer-reviewed version will be provided once the manuscript has been accepted. We encourage feedback to the authors.

\section{4.2 The last and current glacial-interglacial cycle}

\section{4.2.1 Catchment vegetation cover and catchment erosion}

294 Palaeo-sediment residence times are a measure of catchment erosion, which depends on catchment 295 size and morphology, bedrock geology, chemical weathering, vegetation, and climate (Dosseto and 296 Schaller, 2016; Francke et al., 2020a; Thollon et al., 2020). Of these factors, catchment size, 297 morphology, and geology were effectively constant over the time interval investigated herein. Our 298 Monte-Carlo modelling indicates chemical leaching has only limited control on calculated palaeo299 sediment residence times (Supplement 1). Climate (i.e. the amount of rainfall) was also unlikely to 300 directly control erosion, since greater humidity was previously inferred by Forbes et al. (2021) for the 301 period between $130 \mathrm{ka}$ and $115 \mathrm{ka}$ (broadly equivalent to MIS5e) and the Holocene, with both periods 302 characterised by longer palaeo-sediment residence times (Fig. 6). The strong positive loading of 303 Myrtaceae + Casuarinaceae and strong negative loadings of Asteraceae and Poaceae on PLSR 304 predictor axis 1, combined with the strong positive loading of palaeo-sediment residence times on 305 PLSR response axis 1, implies aspects of vegetation can statistically predict catchment erosion and 306 palaeo-sediment residence times (Fig. 5, 6). The representation of Myrtaceae + Casuarinaceae pollen versus Asteraceae and Poaceae probably indicates erosion processes in the Thirlmere catchment are 308 primarily controlled by contrasting vegetation structure as represented by the relative dominance of 309 canopy and mid-storey cover versus understorey elements represented by grasses and herbs. 310 Myrtaceae + Casuarinaceae comprise a wide range of shrubs and trees within the Thirlmere 311 catchment, while Asteraceae and Poaceae summarise a range of grass and herb species (Rose and 312 Martin, 2007, Supplement; Forbes et al., 2021). The strong relationship between catchment erosion 313 and vegetation structure is substantiated by the strong positive phase-relationship between PLSR 314 predictor axis 1 (summarized as canopy and mid-storey cover), PLSR response axis 1 (vegetation- 
This manuscript is a non-peer reviewed EarthArXiv pre-print. A DOI for the peer-reviewed version will be provided once the manuscript has been accepted. We encourage feedback to the authors.

316 The expansion of more open- canopied and mid-storey vegetation communities, with increasing

317 proportions of herbs and grasses, as indicated by Poaceae and Asteraceae has been used as an

318 indicator of dry and/or colder environments in Australia (Black et al., 2006; Williams et al., 2006; Cadd

319 et al., 2021). At Thirlmere, the expansion of Poaceae and Asteraceae along with a reduction in the

320 projective cover by the taller strata (the canopy and mid-storey cover), particularly on the steep

321 slopes and scarps, would result in more open vegetation cover (Fig. 8). These changes would reduce

322 soil stability and promote the erosion of shallow soils and-or deeper erosion across the Thirlmere

323 catchment.

324 A strong control of vegetation structure on erosion also consistent with in-situ ${ }^{10} \mathrm{Be}$ data of soils in 325 the nearby Blue Mountains area, which suggested soil erosion is significantly lower under forests 326 (Wilkinson et al., 2005). That study also revealed a significantly higher soil thickness under forested 327 plateaus compared to mainly heath covered slopes. Previous studies have shown a high soil 328 thickness, in combination with shallow sheetwash erosion under a dense vegetation canopy, 329 translates into longer soil-detrital matter storage, and thus into longer palaeo-sediment residence 330 times (Francke et al., 2019).

331 A meta-analysis of 24 Late Pleistocene to Holocene pollen records has recently shown that vegetation 332 turnover and richness in SE Australia is mainly controlled by moisture (via tropical and westerly wind 333 systems) and sea-level change (controlling oceanic climates, Adeleye et al., 2020). This is consistent 334 with the expansion of herb and grass vegetation during periods of reduced regional precipitation in 335 the Thirlmere catchment between $133.5 \mathrm{ka}$ and $130 \mathrm{ka}$ and between $17.8 \mathrm{cal} \mathrm{ka}$ BP and $11.6 \mathrm{cal} \mathrm{ka}$ 336 BP (Forbes et al., 2021). This supports that moisture has negative feedback on catchment-wide 337 erosion at Thirlmere, with drier climates not promoting slower erosion, but rather faster and deeper 338 erosion, due to the reduction of canopy and mid-storey cover as the vegetation underwent structural change. These findings are also supported from the Murrumbidgee River palaeochannel (300 km SE 
This manuscript is a non-peer reviewed EarthArXiv pre-print. A DOI for the peer-reviewed version will be provided once the manuscript has been accepted. We encourage feedback to the authors.

340 of Lake Couridjah), which has been shown to have palaeo-sediment residence times an order of

341 magnitude lower during glacial compared to interglacial periods (Dosseto et al., 2010).

342 Although occurring at low values only, any occurrence of Acacia pollen (between 0.6 and $3.5 \%$, pollen

343 count generally $<6$, Fig. 4) has been demonstrated to indicate the presence of these species in the

344 mid- to upper strata of sclerophyllous vegetation communities (Dodson, 1983; Black et al., 2007; Rose

345 and Martin, 2007), but Acacia are also an abundant component of the overstorey in the direct vicinity

346 of the lake (Supplement). Acacia are often indicative of drier, or frequently disturbed sclerophyll

347 communities, but they are severely under-represented in fossil pollen data (Mariani et al., 2021). The

348 low pollen count for Acacia in core LC2 complicates the interpretation of this pollen taxa in the 349 palaeo-record. Careful evaluations of our statistical analyses indicate a strong positive (weak 350 negative) loading of Acacia on predictor axis 1 during the last (current) glacial-interglacial cycle. This 351 might suggest a difference on the control of mid-storey and/or taller canopy vegetation in the vicinity 352 of the lake during both the last and current glacial-interglacial cycles, assuming the statistical analyses 353 are not biased by the low pollen counts of Acacia.

354 Between $127 \mathrm{ka}$ and $115 \mathrm{ka}$, Lake Couridjah's catchment vegetation increasingly changed from a 355 canopy and mid-storey dominated vegetation structure to a grass and herb dominated, more-open 356 vegetation structure, as inferred from decreasing Myrtaceae + Casuarinaceae and increasing 357 Asteraceae (Fig. 4, 8). This trend is, however, not mirrored in Acacia and Poaceae, with both taxa 358 appear broadly anticorrelated during this time interval. The high PLSR-derived index of canopy and 359 mid-storey cover between $127 \mathrm{ka}$ to $115 \mathrm{ka}$ is therefore (statistically) mainly controlled by Acacia 360 (Fig. 4), which might imply a relatively high importance of the mid-story vegetation patterns and-or upper canopy strata in the vicinity of the lake for the prediction of vegetation-dependent soil erodibility during the last interglacial cooling (Fig. 6). 
This manuscript is a non-peer reviewed EarthArXiv pre-print. A DOI for the peer-reviewed version will be provided once the manuscript has been accepted. We encourage feedback to the authors.

363

High and stable palaeo-sediment residence between 127 and $123 \mathrm{ka}$, and between 120 to $115 \mathrm{ka}$ imply slower and shallower erosion during periods of increased fire activity and fire-mediated vegetation disturbance (high charcoal surface area $>1 \mathrm{~mm}^{2} / \mathrm{cm}^{3} / \mathrm{yr}$, high sedimentary SPAC content). Frequent disturbance by fire is probably also indicated by highly variable Acacia, and, to some degree Poaceae, which both respond rapidly to fire disturbance, throughout the Late Glacial and Holocene. The high variability in Acacia may (statistically) explain the weak negative loading on PLSR predictor axis 1 during the current glacial-interglacial, implying that Acacia was less significant in controlling soil erosion during the current, compared to the last, glacial-interglacial cycle (where Acacia shows a strong positive loading on predictor axis 1). Frequent disturbance of Acacia may be of particular importance during the Late Glacial, where macroscopic charcoal values are high (Fig. 6).

Late Glacial and Holocene fire activity in the Thirlmere catchment is further refined by charring intensities, as inferred from Attenuated Total Reflectance Fourier Transform Infrared spectra from the same core (Constantine et al., 2021) and increasing Late Glacial to Holocene sedimentary SPAC contents (Fig. 4, Forbes et al., 2021). Fire activity does not appear to have been related to PLSRderived soil erodibility nor to palaeo-sediment residence times during both glacial-interglacial cycles. This is despite evidence of increased erosion and sediment delivery in post-fire rainfall and runoff events attributed to changes in soil properties (water repellency) and opening of vegetation cover (summarised in Shakesby and Doerr, 2006). The soil's water repellence might be increased, decreased, or not alerted depending on fire temperature and duration, which controls infiltration, runoff, and rainsplash detachment (Letey, 2001; Shakesby and Doerr, 2006), all of which may alter sediment supply to Lake Couridjah in post-fire environments. The lack of response in erosion to bushfire activity may be related to (i) the low sample resolution for uranium isotope analyses, (ii) the long timespan covered by samples (typically 80 to 100 years based on the sedimentation rates by Forbes et al., (2021)) providing ample background sedimentation that may overprint the fire signal, 
This manuscript is a non-peer reviewed EarthArXiv pre-print. A DOI for the peer-reviewed version will be provided once the manuscript has been accepted. We encourage feedback to the authors. and-or (ii) by post-fire rainfall characteristics that may control weak post-fire erosion event only

388 (Tomkins et al., 2008).

389 Overall short and variable palaeo-sediment residence times ( $<50 \mathrm{kyrs}$ ) between $115 \mathrm{ka}$ and $107.6 \mathrm{ka}$ show very similar patters to canopy and mid-storey indicators in the pollen record (Myrtaceae + 391 Casuarinaceae, PLSR-derived predictor axis 1), and predicted vegetation-dependent soil erodibility 392 (Fig. 6). Short and decreasing palaeo-sediment residence times ( $<50$ kyrs) indicate accelerated and 393 deeper erosion, when the vegetation structure was dominated by grasses and herbs. Relatively wet 394 conditions, as inferred from a deeper and/or more persistent lake during the same time period 395 (Forbes et al., 2021), could have further promoted deeper and faster catchment erosion, and thus, 396 contributed to the shortest palaeo-sediment residence time recorded in the late last glacial397 interglacial cycle. High lake levels and wetter climates imply that change in vegetation structure between 115 and 107.6 ka was probably rather controlled by temperature than by rainfall. No pollen were preserved on top of the sedimentary hiatus between $107 \mathrm{ka}$ and $17.8 \mathrm{cal}$ ka BP within 400 an oxidised silty clay unit dated between 17.8 cal ka BP and 16 cal ka BP. The long palaeo-sediment 401 residence times (> $90 \mathrm{kyrs}$ ) between $17.8 \mathrm{cal} \mathrm{ka}$ BP and $16 \mathrm{cal}$ ka BP similar to those observed during 402 interglacial periods (130 ka to $115 \mathrm{ka}$, Holocene), are unlikely to be explained by changes in the 403 vegetation cover. Colder and drier climate conditions at the end of the last Glacial (compared to 404 interglacials) likely promoted a similar vegetation structure as observed in other glacial parts of the 405 record (Fig. 4, Cadd et al., 2021). We speculate that higher moisture availability after 17.8 cal ka BP, 406 as indicated by regional climates (Cadd et al., 2021) and the onset of lacustrine deposition at Lake 407 Couridjah (Forbes et al., 2021), mobilised topsoil material or fine-grained material stored in littoral parts of the lake via increased runoff and/or wave action, material that may have previously spent an extended period stored in the catchment. This is also consistent with Forbes et al. (2021)'s 
This manuscript is a non-peer reviewed EarthArXiv pre-print. A DOI for the peer-reviewed version will be provided once the manuscript has been accepted. We encourage feedback to the authors.

410 interpretation that the major hiatus between $107 \mathrm{ka}$ and $17.38 \mathrm{cal}$ ka BP likely resulted from a

411 combination of slow catchment erosion and aeolian deflation.

\section{$412 \quad 4.2 .2$ Soil development}

413 The lower K/Ti in WBRC's soil samples compared to saprolite samples from the same location implies

$414 \mathrm{~K} / \mathrm{Ti}$ ratios can be used as an indicator for the degree of chemical weathering and soil development

415 in the lake's catchment. The absence of correspondence between $\mathrm{K} / \mathrm{Ti}$ and palaeo-sediment

416 residence times for the last and current glacial-interglacial cycle implies a de-coupling between soil

417 development and catchment erosion (Fig. 7H).

418 Warmer and wetter climates as well as tree and forest growth is thought to represent the most

419 important processes affecting chemical weathering (Sverdrup, 2009). A strong control of root-soil

420 structure interactions and warmer and wetter climates on soil development in the Thirlmere

421 catchment is also supported by the moderate strong, statistically significant negative relationship

422 between $\mathrm{K} / \mathrm{Ti}$ and Myrtaceae + Casuarinaceae (Fig. 7H).

423 Limited soil development between 115 and $110 \mathrm{ka}$ is inferred from high K/Ti and corresponds to the

424 transition to relatively open grass and herb vegetation cover, low root-soil structure interactions (low

425 Myrtaceae + Casuarinaceae), and to faster and deeper erosion (low palaeo-sediment residence time,

426 Fig. 4, 7). This indicates a negative feedback between vegetation cover, catchment erosion, and soil

427 development during the late last interglacial cooling phase.

\section{4.2.3 Catchment-wide carbon cycling}

429 Overall faster erosion of thinner soils (short palaeo-sediment residence times, high PLSR vegetation430 dependent soil erodibility) during colder and drier intervals (133.5 ka to $130 \mathrm{ka}, 115 \mathrm{ka}$ to $17.6 \mathrm{ka}$, 431 Late Glacial) could have resulted in high SOC erosion rates, rapidly degrading the relatively thin OM 432 rich topsoil layer described for the modern Thirlmere catchment (section 3.1, Fig. 8). Deeper and 433 faster erosion could have reduced soil-microbial respiration of OM rich topsoil, since material is 
This manuscript is a non-peer reviewed EarthArXiv pre-print. A DOI for the peer-reviewed version will be provided once the manuscript has been accepted. We encourage feedback to the authors.

transported and buried in a sedimentary sink (Chappell et al., 2015). Deeper and faster erosion would also expose SOC from greater soil depths that is mainly comprised of resistant stable soil-C fractions (Chappell et al., 2015). The behaviour of stable C fraction from greater soil depths under deeper erosion is still uncertain, since this carbon pool might be more resistant to mineralisation, reducing $\mathrm{CO}_{2}$ remobilisation into the atmosphere. However, it has also been shown deeper erosion can have 'priming effects' on carbon decomposition via the addition of more labile, 'modern' C, which can increase $\mathrm{CO}_{2}$ remobilisation into the atmosphere (Jandl et al., 2007; Doetterl et al., 2016).

Low $\mathrm{TOC}_{\mathrm{acc}}$ from the sediments of Lake Couridjah imply low net-carbon accumulation within the lake between $133.5 \mathrm{ka}$ and $130 \mathrm{ka}$, between $115 \mathrm{ka}$ and $107.6 \mathrm{ka}$ and during Late Glacial, probably due to limited productivity in the lake, and possibly, limited soil-carbon erosion (Fig. 6, 8). Low soil-C accumulation in the lake, despite fast catchment erosion, was potentially related to overall lower productivity of the open grass and herb vegetation cover (low PLSR-vegetation canopy and midstorey vegetation cover), since the majority of terrestrial biomass is produced by large trees in temperate Australia (Roxburgh et al., 2006). Low terrestrial biomass and mobilisation of mainly minerogenic soils by deeper erosion could have also reduced nutrient supply to the lake, which could, in combination with the inferred cold and climates (Forbes et al., 2021), restrict swamp and aquatic productivity in the lake basin. Limited amounts of aquatic to semi-aquatic (swamp) vegetation (macrophytes, sedges) are inferred from the low abundance of aerophilic + epiphytic diatom taxa (Forbes et al., 2021). Higher planktonic diatom abundances indicate higher lake levels, and the expansion of phytoplankton habitats at this time (Fig. 6). This may indicate that carbon sequestration in Lake Couridjah was more controlled by aquatic productivity of phytoplankton, particularly between $115 \mathrm{ka}$ and $107.6 \mathrm{ka}$, where planktonic diatom abundance was high (Fig. 6). However, the low $\mathrm{TOC}_{\text {acc, }}$ despite the high planktonic diatom abundance (Fig. 6), may indicate that these high lake level phases have a reduced capacity for OM-biomass accumulation, compared to intervals with high 
This manuscript is a non-peer reviewed EarthArXiv pre-print. A DOI for the peer-reviewed version will be provided once the manuscript has been accepted. We encourage feedback to the authors.

$458 \mathrm{TOC}_{\mathrm{acc}}$ and high aerophilic and epiphytic diatom abundance. This is probably due to the low amount 459 of swamp vegetation (providing the substrate for the epiphytic diatoms) being a strong contributor 460 to the lake TOC acc (Forbes et al., 2021). In summary, we infer a lower atmospheric carbon 461 sequestration in the Thirlmere catchment between $133.5 \mathrm{ka}$ and $130 \mathrm{ka}$, between $115 \mathrm{ka}$ to $107.6 \mathrm{ka}$, 462 and during the Late Glacial (compared to the wetter and warmer intervals). Climates were overall 463 colder and drier, resulting in low catchment productivity, deeper and faster erosion, re464 mineralisation of old carbon stored at greater soil depth, limited nutrient supply to the lake, and 465 limited primary productivity by phytoplankton and aquatic to semi-aquatic plants living in the lake 466 (Fig. 8).

467 Shallower and slower erosion (long palaeo-sediment residence times, low PLSR-predicted 468 vegetation-dependent soil erodibility) could have resulted in low SOC erosion rates during warmer 469 and wetter intervals (130 ka to $115 \mathrm{ka}$ and during the Holocene). Long palaeo-sediment residence 470 times (low PLSR-predicted vegetation-dependent soil erodibility) might promote OM oxidation, and, 471 thus, $\mathrm{CO}_{2}$ recycling into the atmosphere (Doetterl et al., 2016). However, a low vegetation-dependent 472 soil erodibility, shallower and slower erosion and a more closed canopy and mid-storey cover could 473 have also fostered longer and deeper SOC storage via bioturbation by roots (Fig. 8).

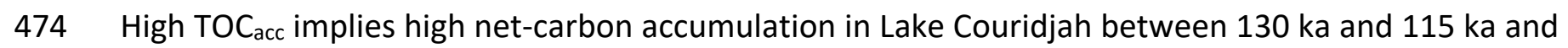
475 during Holocene. High $\mathrm{TOC}_{\mathrm{acc}}$ is attributed to higher primary productivity in the lake basin, as is 476 observable today (Fig. 1). Significantly higher aerophilic and epiphytic diatom abundance implies the 477 increase in $\mathrm{TOC}_{\mathrm{acc}}$ was mainly related to aquatic to semi-aquatic (swamp) vegetation in the lake. 478 Somewhat lower planktonic diatom abundance consequently implies a reduction in planktonic 479 habitats, and lower lake levels. Aquatic and semi-aquatic productivity may be fostered by higher 480 nutrient supply from the catchment during the overall warmer and wetter climates of these periods. 
This manuscript is a non-peer reviewed EarthArXiv pre-print. A DOI for the peer-reviewed version will be provided once the manuscript has been accepted. We encourage feedback to the authors.

481 Significant contributions of terrestrial OM to the lake carbon-pool may have originated from 482 relatively weakly decomposed topsoil SOC mobilised by shallower erosion (section 3.1, Fig. 8). 483 Additionally, more terrestrial OM supply during warmer and wetter intervals despite reduced 484 erosion, could probably be explained by an expansion of a canopy and mid-storey cover (Fi. 6). A 485 canopy and mid-storey cover produces significant amounts of easily transportable, loose leaf litter in 486 the catchment (Gordon et al., 2018), as also observed at the present day (Fig. 1), while a more closed 487 canopy and roots prevents deeper soil erosion despite wetter conditions. In summary, we infer high 488 atmospheric carbon sequestration both in the catchment and the wetland during the overall warmer 489 and wetter periods between $130 \mathrm{ka}$ and $115 \mathrm{ka}$ and during the Holocene (Fig. 8).

\section{Conclusions}

491 Our multiproxy analyses and statistical modelling predict a strong correlation between the vegetation 492 structure in the catchment, erosion, and soil-organic carbon storage. The results imply moisture has 493 an indirect control on catchment-wide erosion at Thirlmere, with wetter climates promoting slower 494 and shallower erosion due the stabilisation of catchment soils by the expansion of more closed and 495 probably more stable vegetation structure. The development of more closed mid-storey and 496 canopied vegetation during warm and humid periods (between $130 \mathrm{ka}$ and $115 \mathrm{ka}$ and during the 497 Holocene) promoted high organic accumulation in the soils but overall reduced SOC erosion. High 498 organic carbon accumulation rates in the lake basin during warmer and wetter periods (between 130 $499 \mathrm{ka}$ and $115 \mathrm{ka}$ and during the Holocene) are attributed to high biomass productivity within the lake 500 and the catchment. This implies an overall high potential for catchment-wide atmospheric carbon 501 dioxide sequestration during the Holocene and between $130 \mathrm{ka}$ and $115 \mathrm{ka}$ (broadly equivalent to 502 MIS5e). 
This manuscript is a non-peer reviewed EarthArXiv pre-print. A DOI for the peer-reviewed version will be provided once the manuscript has been accepted. We encourage feedback to the authors.

503 Erosion was high during colder and drier periods (133.5 ka to $130 \mathrm{ka}, 115 \mathrm{ka}$ to $107.6 \mathrm{ka}$, Late Glacial),

504 when relatively open vegetation structure promoted deeper and faster erosion of thin soils. Low

505 aquatic and terrestrial biomass production and high SOC erosion rates during colder and drier

506 intervals imply low catchment-wide atmospheric carbon sequestration between $133.5 \mathrm{ka}$ and $130 \mathrm{ka}$,

$507115 \mathrm{ka}$ and $107.6 \mathrm{ka}$, and during the Late Glacial.

508 Our research was conducted at a site with climatic, lithologic, and plant-species communities 509 representative for SE Australia more broadly. The controls of catchment erosion in the Thirlmere 510 catchment are furthermore supported by previous studies in the Blue Mountains (nearby Sydney) 511 and the Murrumbidgee catchment (approximately $300 \mathrm{~km}$ to the southeast). This suggests our 512 findings provide insight into the interplay of erosion and soil-carbon cycling across the broader region 513 of SE Australia, which has previously been characterised as globally significant terrestrial carbon sink.

\section{Declaration of competing interest}

515 The authors declare that they have no known competing financial interests or personal relationships 516 that could have appeared to influence the work reported in this paper.

\section{Acknowledgment}

518 We wish to acknowledge the long connection held by the First Nations peoples of the Dharawal 519 people, who are the first custodians of the Woolyungah Country, which includes the Thirlmere lakes.

520 This research was funded by the New South Wales Department of Environment and Heritage (OEH) 521 as part of the Thirlmere Lakes Research Program to TC, AD and SM. Geochronology and laboratory 522 analyses were supported by funding from the Australian Research Council Centres of Excellence 523 Scheme (Project Number CE170100015). Special thanks also goes to Emily Barber, Andres Zamora, 
This manuscript is a non-peer reviewed EarthArXiv pre-print. A DOI for the peer-reviewed version will be provided once the manuscript has been accepted. We encourage feedback to the authors.

524 Elizabeth Swallow, Heather Haines, Brian Jones all of whom were a key part of the Thirlmere team 525 when core LC2 was analysed.

\section{Figure Captions}

528 Fig. 1: A: Location of the Thirlmere lakes in SE Australia. B: Location of Lake Couridjah (lake 3) in

529 Thirlmere Lakes system. White arrow indicates the location of Dry Lake C: Location of core LC2. Black 530 line $a^{\prime}$ to $a^{\prime \prime}$ represents the vegetation and sediment transect presented in D. Black arrows and 531 shaded area highlight the alluvial fan separating lakes Couridjah and Baraba. D: Topographic cross532 section for the Lake Couridjah catchment ( $a^{\prime}$ to $\left.a^{\prime \prime}\right)$. A to E in red indicate the major geomorphic and 533 vegetation zones around Lake Couridjah, as shown in pictures in the lower pannel. Modified after 534 Forbes et al. (2021).

536 Fig. 2: Conceptual model of detrital matter transit from source to sink. Depletion of ${ }^{234} U$ starts in fine537 grained detrital matter that is produced as the weathering front on the hillslopes migrates downward 538 over time. Further lowering of the $\left({ }^{234} \mathrm{U} /{ }^{238} \mathrm{U}\right)$ activity ratio occurs in any process related to hillslope 539 and fluvial storage and transport, and during final deposition in a

540 sedimentary basin. The time excluding final deposition represents the palaeo-sediment residence 541 time. Modified after Dosseto and Schaller (2016)

543 Fig. 3: $\left({ }^{234} \mathrm{U} /{ }^{238} \mathrm{U}\right)$ activity ratio, $\delta^{13} \mathrm{C}_{\text {soil, }} \delta^{15} \mathrm{~N}_{\text {soil }}$ isotope and elemental (TOC, TN, K/Ti) data of the 544 WBRC soil pit from the catchment of Lake Werri Berri. The site is considered representative for the 545 catchment of Lake Couridjah due to the homogenous bedrock lithology in the Thirlmere catchment. 546 Carbon and nitrogen isotope data of leaf litter are from after Forbes et al. (2021). Correlation 
This manuscript is a non-peer reviewed EarthArXiv pre-print. A DOI for the peer-reviewed version will be provided once the manuscript has been accepted. We encourage feedback to the authors.

coefficients and probabilities for correlations between isotope and elemental data are reported in

$548 \quad$ Fig. S3.

550 Fig. 4: Terrestrial pollen, charcoal surface area, and SPAC content for the last and current glacial to 551 interglacial cycle. Pollen, charcoal, and SPCA data were previously published by Forbes et al. (2021).

552 Terrestrial pollen percentages were re-calculated by excluding all aquatic and semi-aquatic taxa as 553 well as Chenopodiaceae, which occurred at very low pollen counts only.

555 Fig. 5: PLSR loadings for predictor (recalculated, terrestrial pollen taxa Acacia, Asteraceae, Poacea, 556 Mytraceae + Casuarinaceae) and response (palaeo-sediment residence times) variables. PLSR 557 analyses were carried out separately for the current (top panel, 17.3 cal ka BP to present day) and 558 last (bottom panel, 133,5 ka to $1107.6 \mathrm{ka}$ ) glacial to interglacial cycle.

560 Fig. 6: Palaeo-sediment residence times, $\delta^{13} C_{\text {lake, }} \delta^{15} \mathrm{~N}_{\text {lake, }} \mathrm{K} / \mathrm{Ti}, \mathrm{TOC}$ acc, diatom, and PLSR-derived mid561 upper story vegetation density and vegetation-depended soil erodibility versus age. The age model 562 was previously published by Forbes et al. (2021). Dashed vertical lines mark major climate boundaries 563 of the penultimate glacial, early last interglacial (broadly equivalent to MIS5e), late last interglacial, 564 Late Glacial, and Holocene. Note reverse scale for $\mathrm{K} / \mathrm{Ti}$. Total diatom abundance is balanced by 565 species classified as "others" if they could not be classified as of Aerophilic, Epiphytic or Planktonic 566 (see Forbes et al., 2021 for more details).

568 Fig. 7: Scatter plots, correlation coefficients and probabilities for palaeo-sediment residence times, 
This manuscript is a non-peer reviewed EarthArXiv pre-print. A DOI for the peer-reviewed version will be provided once the manuscript has been accepted. We encourage feedback to the authors.

570

571

572

573

574

575

576

577

578

579

580

581

582

583

584

585

586

587

588

589

590

591

592

593

594

595

596

597

598

599

600

601

602

603

604

605

606

607

LC2, i.e. statistical analyses presented in Fig. 7 were not carried out separately for the current and

last glacial to interglacial cycle as conducted for PLSR analyses.

Fig. 8: Conceptual model of vegetation change, catchment erosion, SOC-mobilisation, and lakeproductivity in the Thirlmere catchment during warmer and wetter (peak-last interglacial, Holocene) and colder and drier (penultimate glacial, late-last interglacial and Late Glacial) periods. Letters A to D mark different landscapes in the Thirlmere catchment and are the same as for Fig. 1D.

\section{Bibliography}

Adeleye, M.A. et al., 2020. Long-term drivers of vegetation turnover in Southern Hemisphere temperate ecosystems. Global Ecology and Biogeography.

Black, M.P., Mooney, S.D., Haberle, S.G., 2007. The fire, human and climate nexus in the Sydney Basin, eastern Australia. The Holocene, 17(4): 469-480.

Black, M.P., Mooney, S.D., Martin, H.A., 2006. A >43,000-year vegetation and fire history from Lake Baraba, New South Wales, Australia. Quaternary Science Reviews, 25(21-22): 3003-3016.

Bureau of Meteorology, 2021. Australian climate data from 1889 to yesterday.

Cadd, H. et al., 2021. A continental perspective on the timing of environmental change during the last glacial stage in Australia. Quaternary Research, 102: 5-23.

Chappell, A., Baldock, J., Sanderman, J., 2015. The global significance of omitting soil erosion from soil organic carbon cycling schemes. Nature Climate Change, 6(2): 187-191.

Constantine, M. et al., 2021. Using charcoal, ATR FTIR and chemometrics to model the intensity of pyrolysis: Exploratory steps towards characterising fire events. Science of The Total Environment, 783.

DePaolo, D.J., Maher, K., Christensen, J.N., McManus, J., 2006. Sediment transport time measured with U-series isotopes: Results from ODP North Atlantic drift site 984. Earth and Planetary Science Letters, 248(1-2): 394-410.

Dodson, J.R., 1983. Modern pollen rain in southeastern new South Wales, Australia. Review of Palaeobotany and Palynology, 38(3): 249-268.

Doetterl, S. et al., 2016. Erosion, deposition and soil carbon: A review of process-level controls, experimental tools and models to address C cycling in dynamic landscapes. Earth-Science Reviews, 154: 102-122.

Dosseto, A., Hesse, P.P., Maher, K., Fryirs, K., Turner, S., 2010. Climatic and vegetation control on sediment dynamics during the last glacial cycle. Geology, 38(5): 395-398.

Dosseto, A., Schaller, M., 2016. The erosion response to Quaternary climate change quantified using uranium isotopes and in situ-produced cosmogenic nuclides. Earth-Science Reviews, 155: 6081.

Dosseto, A., Turner, S.P., Chappell, J., 2008. The evolution of weathering profiles through time: New insights from uranium-series isotopes. Earth and Planetary Science Letters, 274(3-4): 359371. 
This manuscript is a non-peer reviewed EarthArXiv pre-print. A DOI for the peer-reviewed version will be provided once the manuscript has been accepted. We encourage feedback to the authors.

608

609

610

611

612

613

614

615

616

617

618

619

620

621

622

623

624

625

626

627

628

629

630

631

632

633

634

635

636

637

638

639

640

641

642

643

644

645

646

647

648

649

650

651

652

653

654
Forbes, M. et al., 2021. Comparing interglacials in eastern Australia: A multi-proxy investigation of a new sedimentary record. Quaternary Science Reviews, 252.

Francke, A., Carney, S., Wilcox, P., Dosseto, A., 2018. Sample preparation for determination of comminution ages in lacustrine and marine sediments. Chemical Geology, 479: 123-135.

Francke, A. et al., 2019. Sediment residence time reveals Holocene shift from climatic to vegetation control on catchment erosion in the Balkans. Global and Planetary Change, 177: 186-200.

Francke, A. et al., 2020a. Geochemical methods to infer landscape response to Quaternary climate change and land use in depositional archives: A review. Earth-Science Reviews, 207: 103218.

Francke, A., Dosseto, A., Just, J., Wagner, B., Jones, B.G., 2020b. Assessment of the controls on $(234 \mathrm{U} / 238 \mathrm{U})$ activity ratios recorded in detrital lacustrine sediments. Chemical Geology, 550: 119698.

Gordon, C.E., Bendall, E.R., Stares, M.G., Collins, L., Bradstock, R.A., 2018. Aboveground carbon sequestration in dry temperate forests varies with climate not fire regime. Glob Chang Biol, 24(9): 4280-4292.

Haverd, V. et al., 2013. The Australian terrestrial carbon budget. Biogeosciences, 10(2): 851-869.

Haverd, V., Smith, B., Trudinger, C., 2016. Dryland vegetation response to wet episode, not inherent shift in sensitivity to rainfall, behind Australia's role in 2011 global carbon sink anomaly. Glob Chang Biol, 22(7): 2315-6.

Horsfall, L., Jelinek, A., Timms, B.V., 1988. The influence of recreation, mainly power boating, on the ecology of the Thirlmere Lakes, N.S.W., Australia. SIL Proceedings, 1922-2010, 23(1): 580-587.

Kaplan, J.O., Krumhardt, K.M., Zimmermann, N., 2009. The prehistoric and preindustrial deforestation of Europe. Quaternary Science Reviews, 28(27): 3016-3034.

Klein Goldewijk, K., Beusen, A., Doelman, J., Stehfest, E., 2017. Anthropogenic land use estimates for the Holocene - HYDE 3.2. Earth System Science Data, 9(2): 927-953.

Letey, J., 2001. Causes and consequences of fire-induced soil water repellency. Hydrological Processes, 15(15): 2867-2875.

Li, F. et al., 2020. Towards quantification of Holocene anthropogenic land-cover change in temperate China: A review in the light of pollen-based REVEALS reconstructions of regional plant cover. Earth-Science Reviews, 203: 103119.

$\mathrm{Li}$, L. et al., 2018. Weathering dynamics reflected by the response of riverine uranium isotope disequilibrium to changes in denudation rate. Earth and Planetary Science Letters, 500: 136144.

Lugato, E. et al., 2018. Soil erosion is unlikely to drive a future carbon sink in Europe. Science Advances, 4(11): eaau3523.

Luo, Y. et al., 2016. Toward more realistic projections of soil carbon dynamics by Earth system models. Global Biogeochemical Cycles, 30(1): 40-56.

Mariani, M. et al., 2021. Disruption of cultural burning promotes shrub encroachment and unprecedented wildfires. Frontiers in Ecology and the Environment.

Martin, A.N. et al., 2019. Sediment residence times in catchments draining to the Gulf of Carpentaria, northern Australia, inferred by uranium comminution dating. Geochimica et Cosmochimica Acta, 244: 264-291.

Poulter, B. et al., 2014. Contribution of semi-arid ecosystems to interannual variability of the global carbon cycle. Nature, 509(7502): 600-3.

Reynolds, B.C., Wasserburg, G.J., Baskaran, M., 2003. The transport of U- and Th-series nuclides in sandy confined aquifers. Geochimica et Cosmochimica Acta, 67(11): 1955-1972.

Rose, S., Martin, H.A., 2007. The Vegetation History of the Holocene at Dry Lake, Thirlmere, New South Wales. Proceedings of the Linnean Society of New South Wales, 128: 15-55. 
This manuscript is a non-peer reviewed EarthArXiv pre-print. A DOI for the peer-reviewed version will be provided once the manuscript has been accepted. We encourage feedback to the authors.

655

656

657

658

659

660

661

662

663

664

665

666

667

668

669

670

671

672

673

674

675

676

677

678

679

680

681

682

683

684

685

686

687

688

689

690

691

Rothacker, L. et al., 2018. Impact of climate change and human activity on soil landscapes over the past 12,300 years. Scientific Reports, 8(1): 247.

Roxburgh, S.H., Wood, S.W., Mackey, B.G., Woldendorp, G., Gibbons, P., 2006. Assessing the carbon sequestration potential of managed forests: a case study from temperate Australia. Journal of Applied Ecology, 43(6): 1149-1159.

Shakesby, R., Doerr, S., 2006. Wildfire as a hydrological and geomorphological agent. Earth-Science Reviews, 74(3-4): 269-307.

Short, M.A. et al., 2020. Two centuries of water-level records at Lake George, NSW. Australian Journal of Earth Sciences: 1-20.

Sugita, S., 2007a. Theory of quantitative reconstruction of vegetation I: pollen from large sites REVEALS regional vegetation composition. The Holocene, 17(2): 229-241.

Sugita, S., 2007b. Theory of quantitative reconstruction of vegetation II: all you need is LOVE. The Holocene, 17(2): 243-257.

Suresh, P.O., Dosseto, A., Hesse, P.P., Handley, H.K., 2013. Soil formation rates determined from uranium-series isotope disequilibria in soil profiles from the southeastern Australian highlands. Earth and Planetary Science Letters, 379: 26-37.

Sverdrup, H., 2009. Chemical weathering of soil minerals and the role of biological processes. Fungal Biology Reviews, 23(4): 94-100.

Thollon, M. et al., 2020. The distribution of (234U/238U) activity ratios in river sediments. Geochimica et Cosmochimica Acta, 290: 216-234.

Timms, B.V., 1992. Lake Geomorphology. Gleneagles Publishing, Adelaide.

Tomkins, K.M. et al., 2008. Postwildfire hydrological response in an El Niño-Southern Oscillationdominated environment. Journal of Geophysical Research, 113(F2).

Tomkins, K.M. et al., 2004. Mass movement events in the south-west Sydney basin during the Holocene Regolith. In: I.C., R. (Ed.), Regolith 2004. CRC LEME, pp. 365-369.

Trondman, A.K. et al., 2015. Pollen-based quantitative reconstructions of Holocene regional vegetation cover (plant-functional types and land-cover types) in Europe suitable for climate modelling. Glob Chang Biol, 21(2): 676-97.

van Dijk, A.I.J.M. et al., 2013. The Millennium Drought in southeast Australia (2001-2009): Natural and human causes and implications for water resources, ecosystems, economy, and society. Water Resources Research, 49(2): 1040-1057.

Wilkinson, M.T. et al., 2005. Soil production in heath and forest, Blue Mountains, Australia: influence of lithology and palaeoclimate. Earth Surface Processes and Landforms, 30(8): 923-934.

Williams, N.J., Harle, K.J., Gale, S.J., Heijnis, H., 2006. The vegetation history of the last glacialinterglacial cycle in eastern New South Wales, Australia. Journal of Quaternary Science, 21(7): 735-750. 


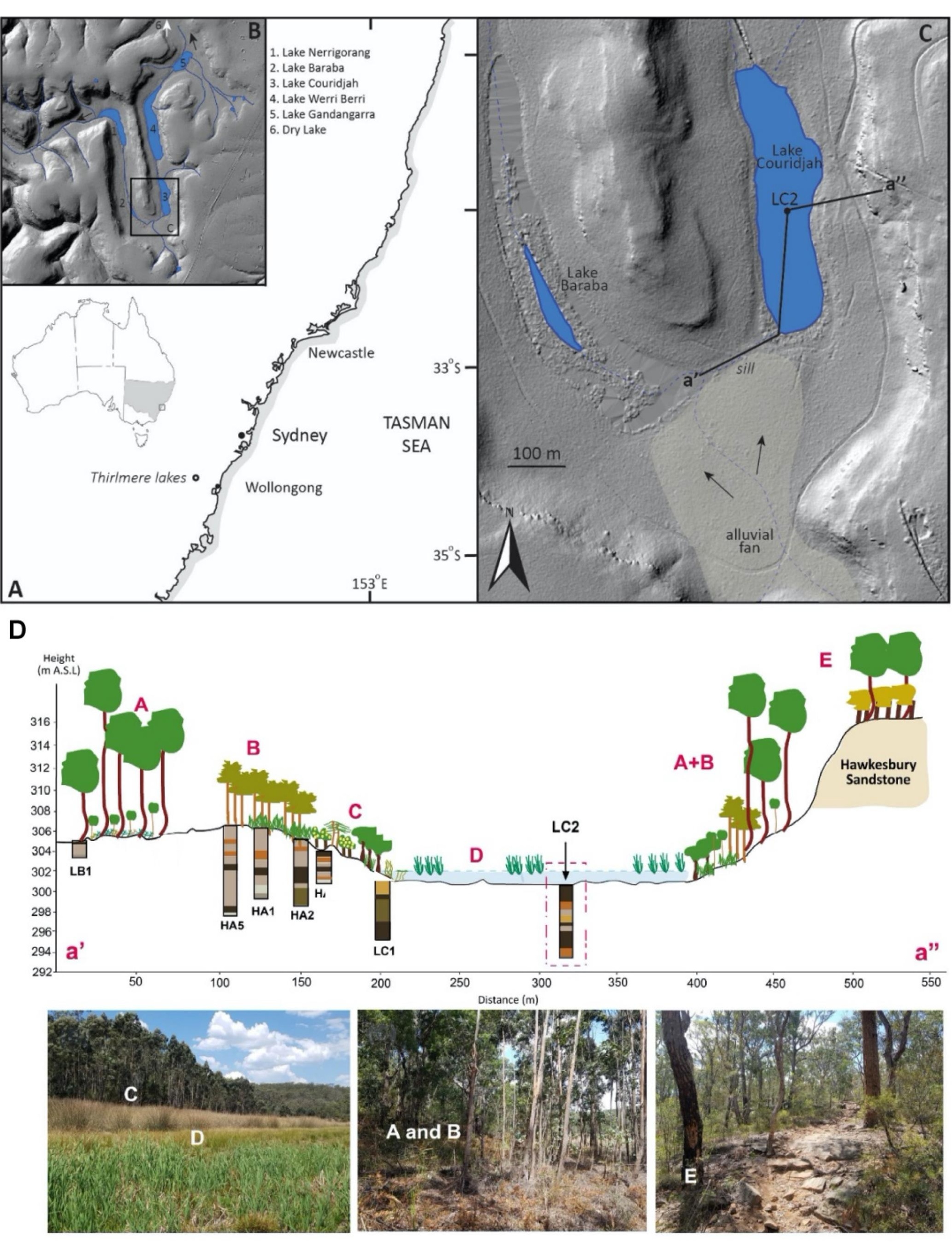

Fig. 1 


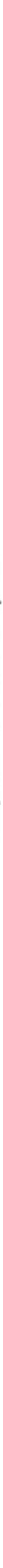

Fig. 2 


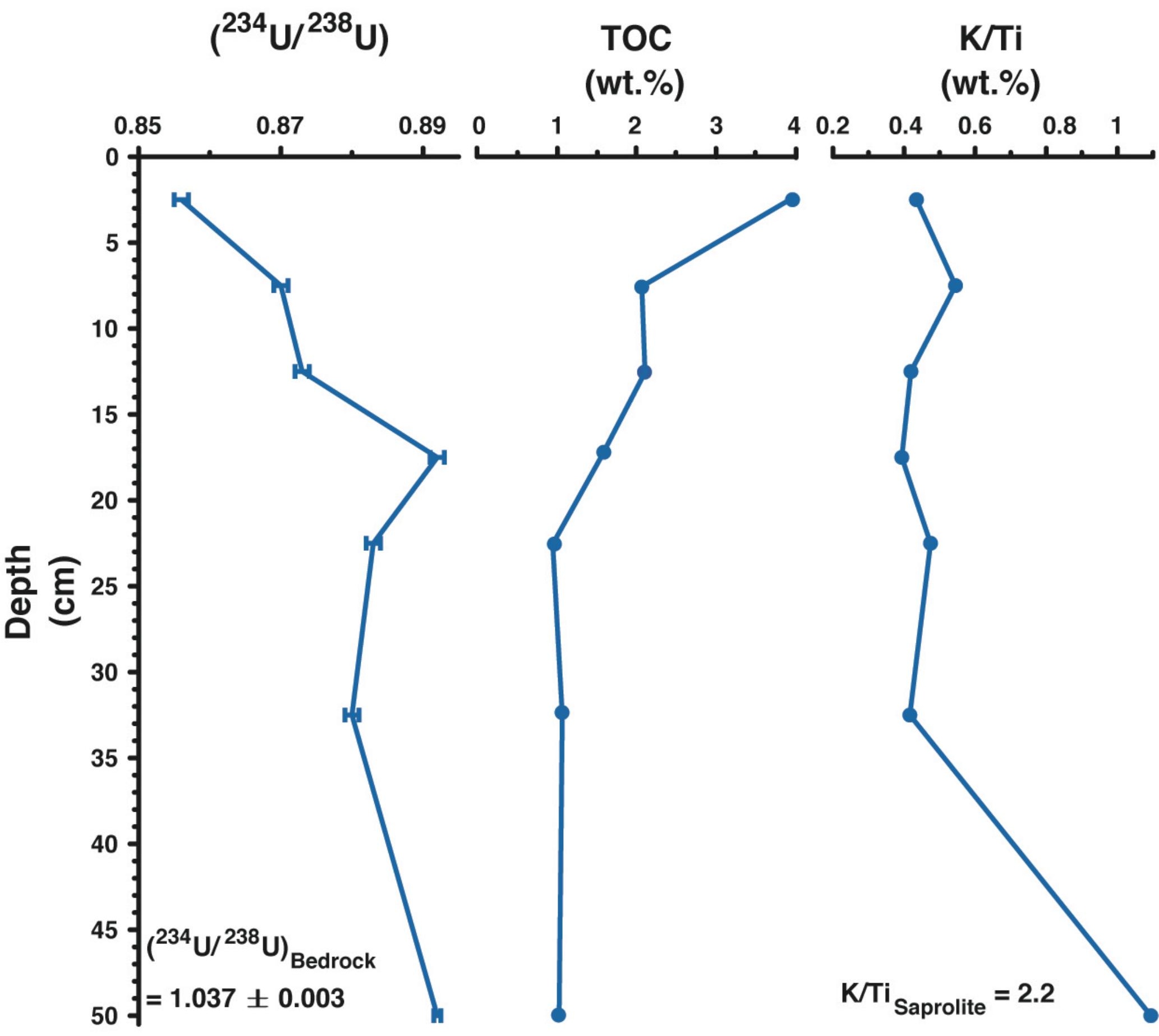

Fig. 3 
Current

Glacial-Interglacial Cycle
Last

Glacial-Interglacial Cycle

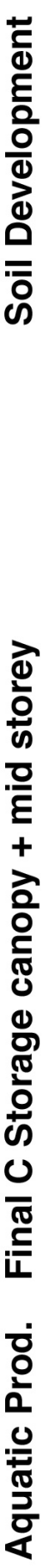
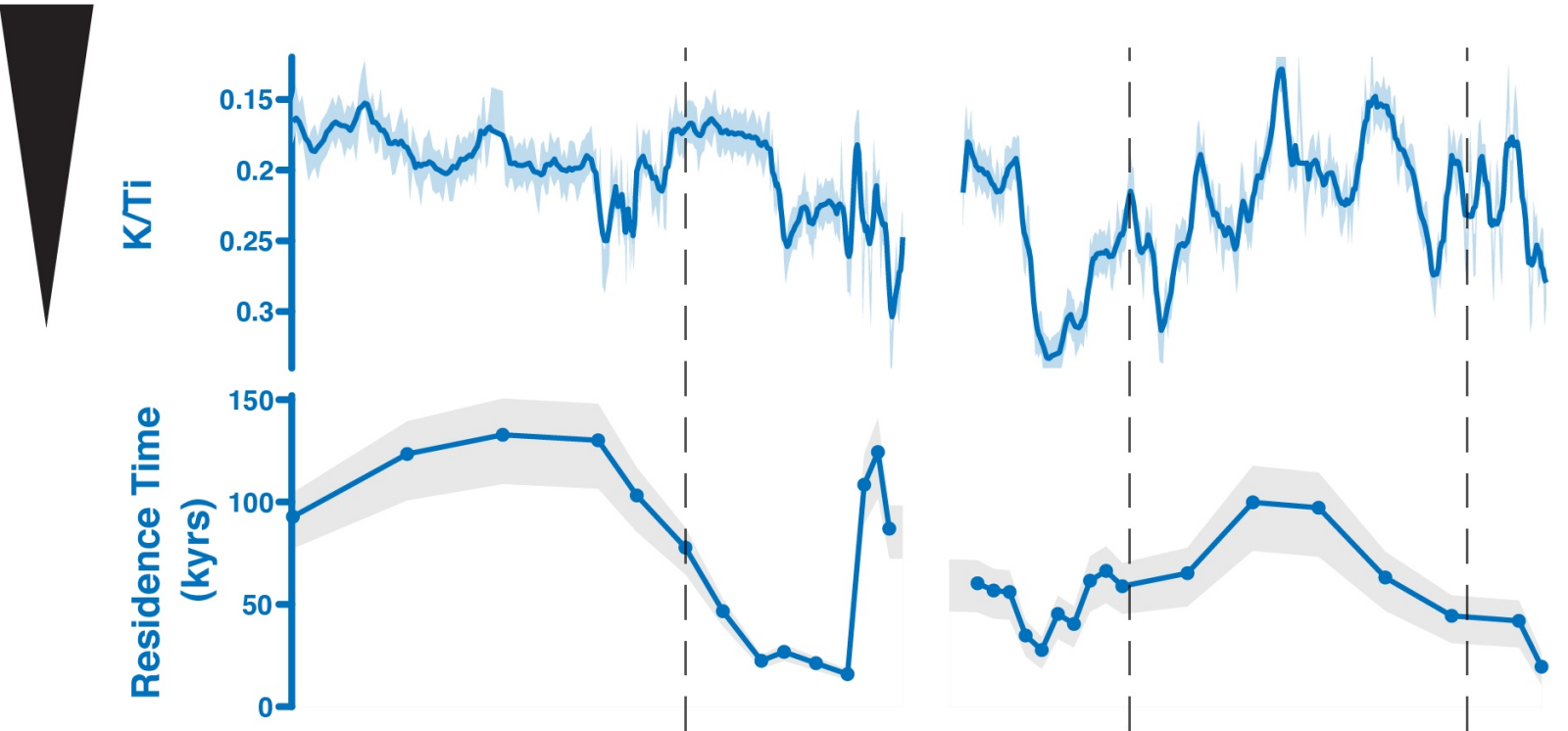

y
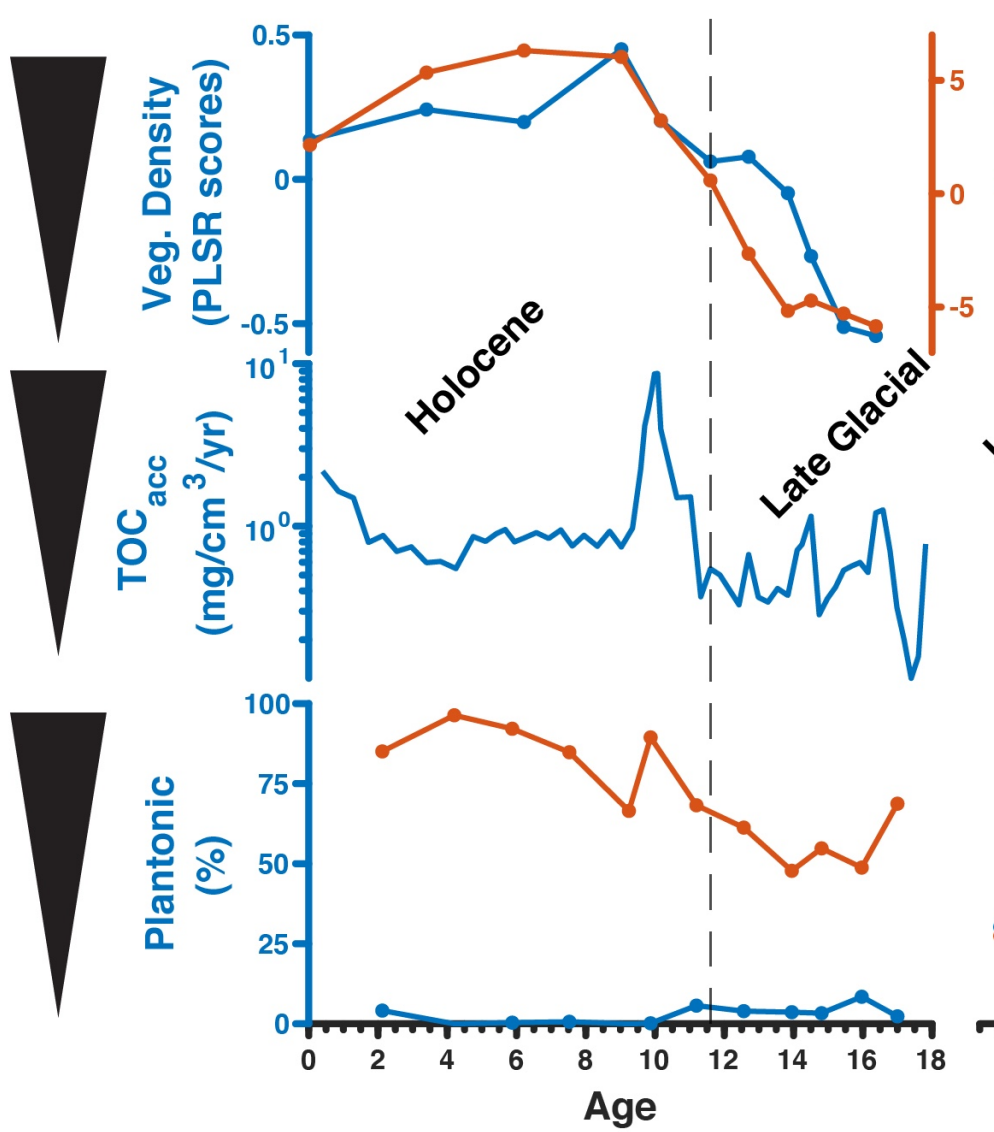

(cal yr BP)

Fig. 6

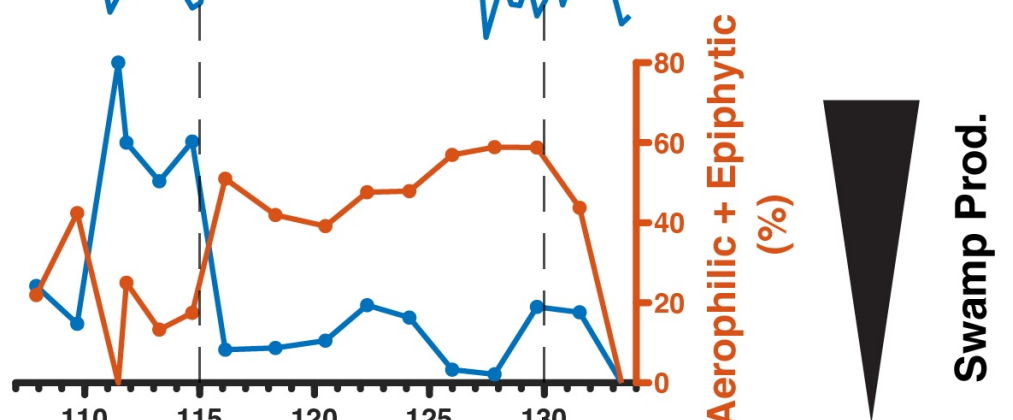

Age

(ka) 

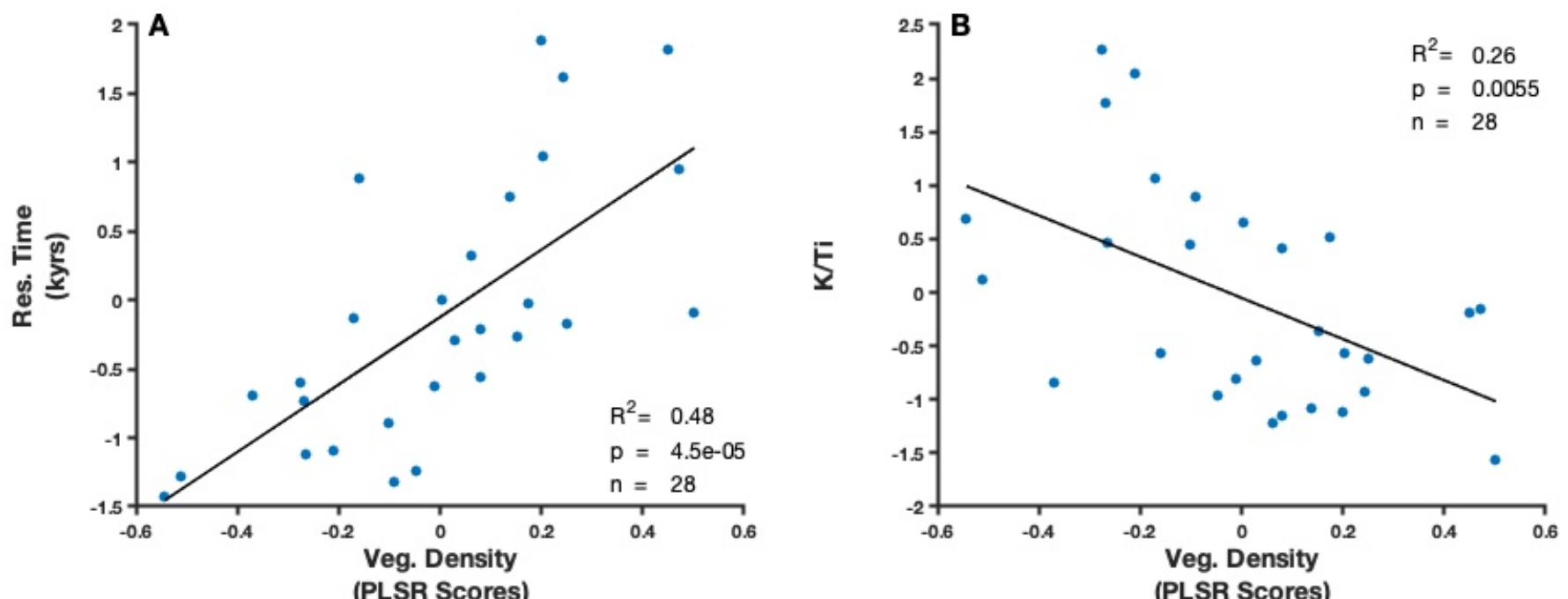

(PLSR Scores)
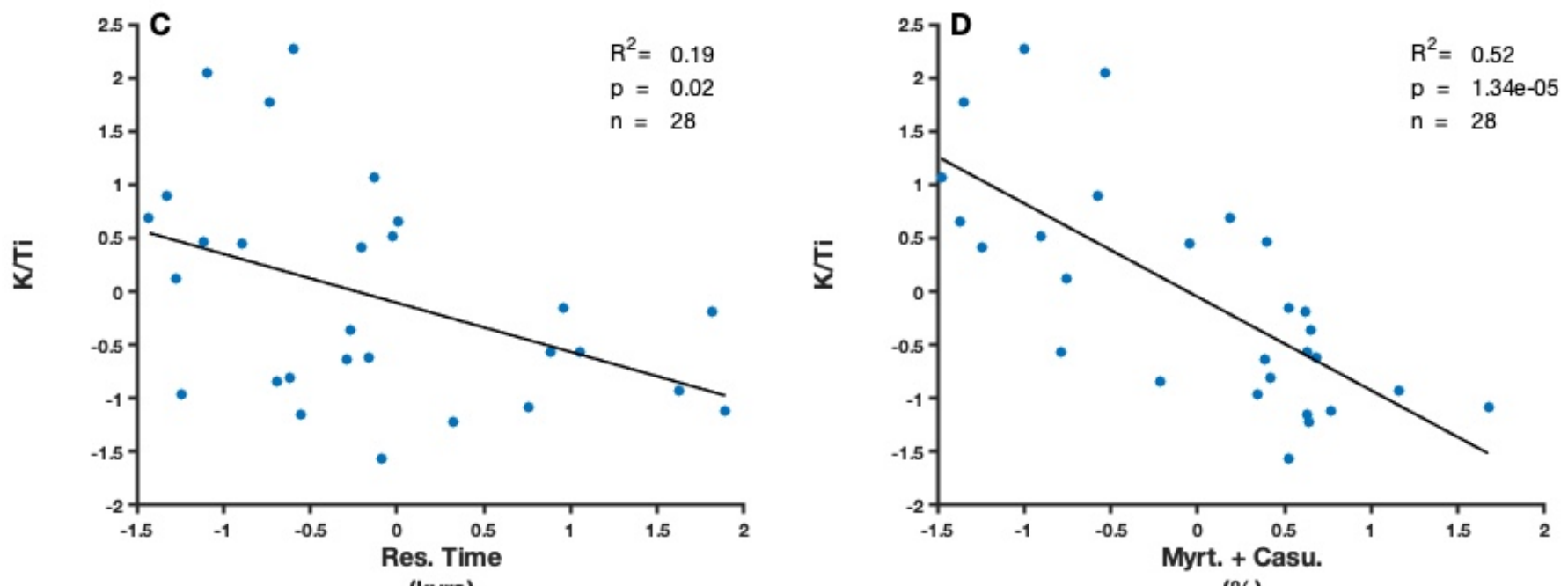

(kyrs)

(\%) 


\section{Warmer and wetter conditions}

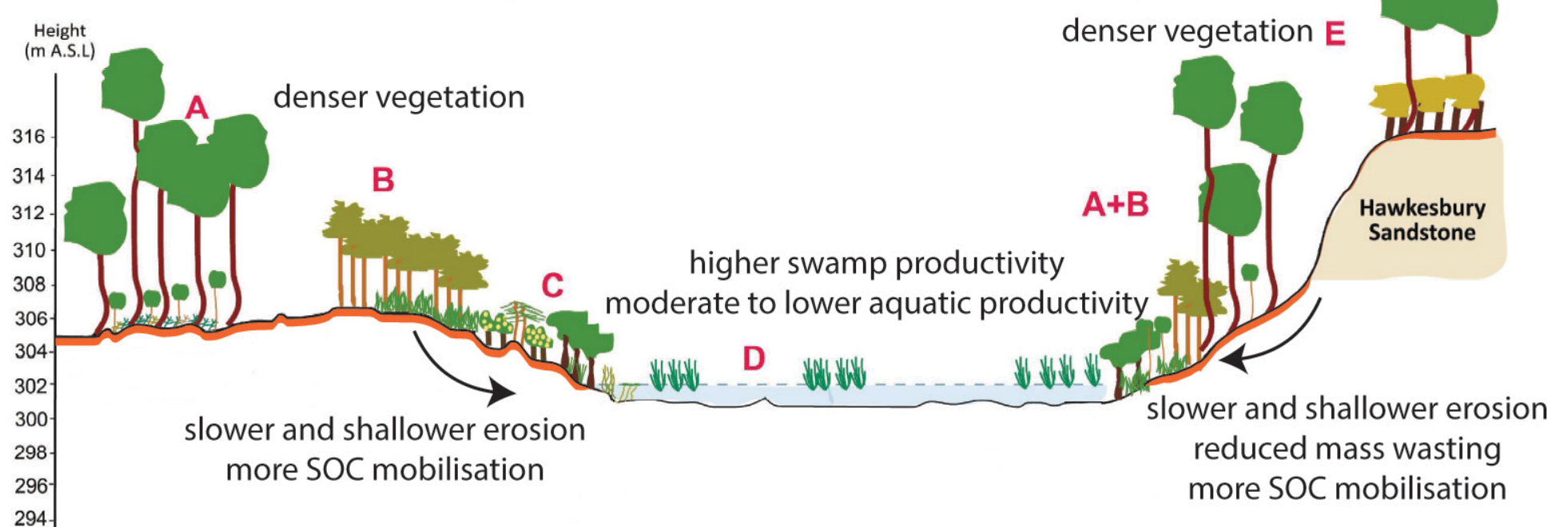

\section{Colder and drier conditions}

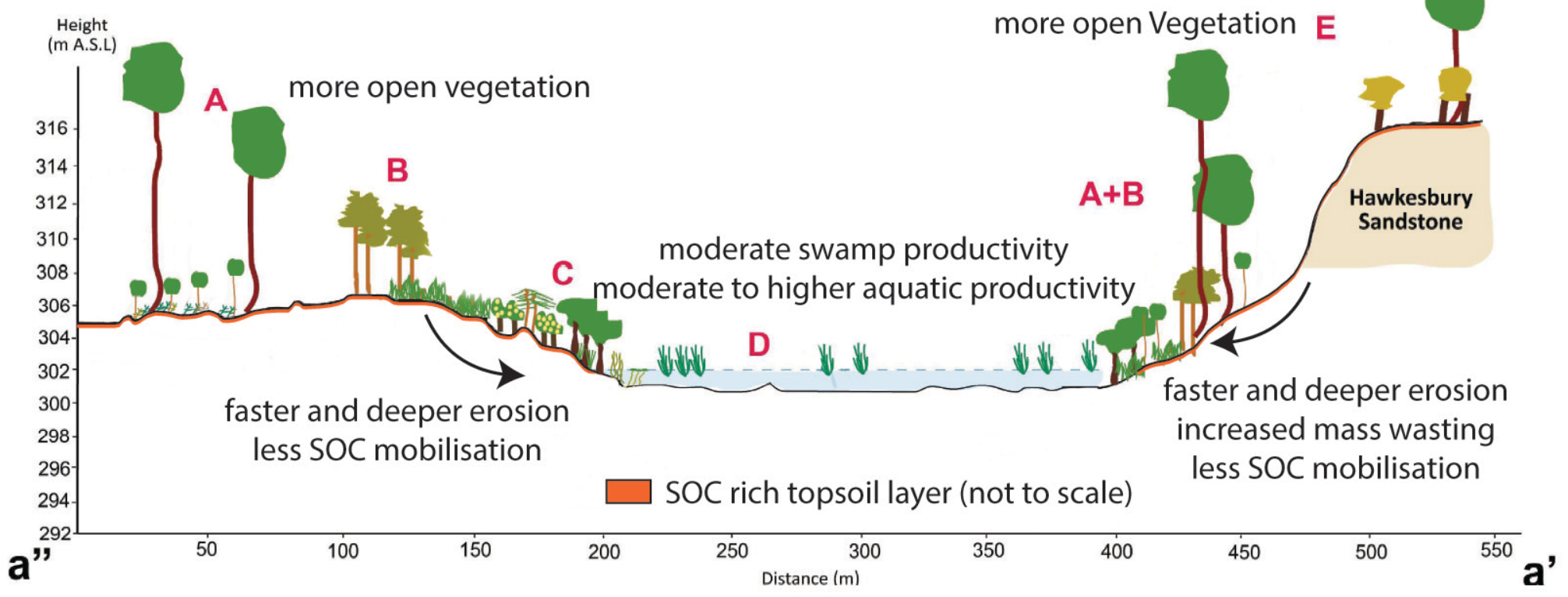


This manuscript is a non-peer reviewed EarthArXiv pre-print. A DOI for the peer-reviewed version will be provided once the manuscript has been accepted. We encourage feedback to the authors.

\section{Supplement}

\section{1. Regional settings}

3 The detailed survey of the contemporary vegetation patterns in the direct vicinity of Lake Couridjah

4 by Forbes et al. (2021) imply that open mixed sclerophyll forest (mainly Myrtaceae incl. Eucalyptus

5 piperita, E. nitens and E. deanei, Corymbia gummifera and C. eximia) cover the top of the ridge crests 6 and the alluvial fans to the north and south of Lake Couridjah, as well as gullies and slopes along the eastern and western flank of the lake (Areas A, B, and E in Fig. 1). Open dry sclerophyll midstory in the same areas mainly composes of Casuarinaceae (Allocasuarina torulosa), Proteaceae (Xylomelum pyriforme, Persoonia linearis, Banksia serrata), and Apiaceae (Platysace linearfolia). Fabaceae (Acacia longifolia, Acacia linearfolia) and Dennstaedtiaceae (Histiopteris incisa) are most prominent midstory

11 vegetation in closer proximity to the lake but can also be found on the alluvial fans and top of the

12 ridge crests. The lake margin and lakebed of Lake Couridjah are covered by Cyperaceae (Lepironia

13 articulata, Lepidosperma longitudinale) during wetter intervals, and by herbs and other species 14 including Gonocarpus micranthus (Haloragaceae), Cyperus difformis and Juncus planifolius 15 (Cyperaceae), Philydrum lanuginosum (Philydraceae) and invasive species like Paspalum dilatatum 16 (Poaceae) during dry periods. Vegetation growing in the lake (during wetter periods) and on the 17 lakebed (during dryer periods) promote the formation of a peat/swamp environment at Lake 18 Couridjah today.

\section{2. Methods}

\subsection{Major element and stable isotope geochemistry (WBRC1 soil pit)}

21 Total organic carbon (TOC) analyses was determined after combustion at $1150^{\circ} \mathrm{C}$ using a vario MICRO 22 cube element analyser (Elementar) as released $\mathrm{CO}_{2}$ and $\mathrm{N}_{2}$ at the University of Wollongong 23 (Wollongong, Australia). Conventional XRF analyses (for Ti and $\mathrm{K}$ content) were first combusted at $24960^{\circ} \mathrm{C}$ to determine loss on ignition (LOI), mixed with flux and then fused at $1150^{\circ}$ in Pt-Au (platinum25 gold) crucibles. Element concentration analysis was conducted on pressed powder pellets and 26 analysed at the University of Wollongong (Wollongong, Australia) using a desktop Spectro XEPOS 27 energy dispersive spectrometer. 
This manuscript is a non-peer reviewed EarthArXiv pre-print. A DOI for the peer-reviewed version will be provided once the manuscript has been accepted. We encourage feedback to the authors.

\subsection{Uranium isotope analyses}

29 A Neptune Plus (ThermoScientific) Multi-Collector Inductive Coupled Plasma Mass Spectrometer 30 (MC-ICP MS) equipped with a PFA-self aspirating nebulizer and an ESI Apex IR desolvator for 31 introduction of samples and standards was used for uranium isotope analyses. After passing through 32 a jet sample and $x$ skimmer cones, ${ }^{235} \mathrm{U}$ and ${ }^{238} \mathrm{U}$ were collected on Faraday cups, while a secondary 33 electron multiplier (SEM) equipped with a retarding potential quadrupole (RPQ) was used to collect $34{ }^{234} \mathrm{U}$ and ${ }^{236} \mathrm{U}$. Correction for mass bias and SEM/Faraday cup yield and precision was assessed by analysing a synthetic standard NBL U010 before and after each sample. Isotopic ratios are reported as $\left({ }^{234} \mathrm{U} /{ }^{238} \mathrm{U}\right)$ activity ratios. Standard deviation from a NBL U005A synthetic standard at the start and end of each sequence was consistently better than $0.5 \%$ (Table 1 ). Total procedure blanks showed that blanks contributed $<0.2 \%$ to the analysed isotopic ratios. Accuracy and precision were assessed by analysing USGS BCR-2 and QLO-01a reference materials and in total six replicates from the core and soil pit samples (Table 1). Reference material, primary and secondary standards was evaluated against expected accuracy from the literature (Sims et al., 2008). U concentrations were determined by isotope dilution for all double ${ }^{236} \mathrm{U} /{ }^{229} \mathrm{Th}$ spiked samples, and by means of quadrupole ICP-MS analyses at the University of Wollongong for all other samples.

\section{$44 \quad 2.2$ Surface area and surface properties}

45 Surface area and surface properties were analysed by gas absorption analysis on a Quantachrome 46 Autosorb iQ. Samples were first degassed for $7.5 \mathrm{~h}\left(5^{\circ} \mathrm{C} / \mathrm{min}\right.$ to $80^{\circ} \mathrm{C}$, soak time $30 \mathrm{~min}$, followed by $471^{\circ} \mathrm{C} / \mathrm{min}$ to $100{ }^{\circ} \mathrm{C}$, soak time $60 \mathrm{~min}$, followed by $5^{\circ} \mathrm{C} / \mathrm{min}$ to $200^{\circ} \mathrm{C}$, soak time $300 \mathrm{~min}$ ). Best fit of 48 the Multi-point BET equation was used to determine the specific surface area. Micropores not 49 relevant for loss by ${ }^{234} \mathrm{Th}$ recoil were determined and subtracted by using the t-method of Halsey 50 (1948).

\section{$51 \quad 2.3$ Palaeo-sediment residence time calculations}

52 Palaeo-sediment residences times were calculated based on a modified equation to that of DePaolo 53 et al. (2006). The new equation of Francke et al. (2020) is based on those of Dosseto and Schaller 54 (2016) and allows accounting for realistic values of pre- and post-depositional leaching of ${ }^{234} U$ and 55 limited loss of ${ }^{234} \mathrm{Th}$ after final deposition, which can overprint the actual recoil loss of ${ }^{234} \mathrm{U}$ since 56 comminution by ${ }^{234} \mathrm{Th}$ recoil. The modified equation reads as follows: 
This manuscript is a non-peer reviewed EarthArXiv pre-print. A DOI for the peer-reviewed version will be provided once the manuscript has been accepted. We encourage feedback to the authors.

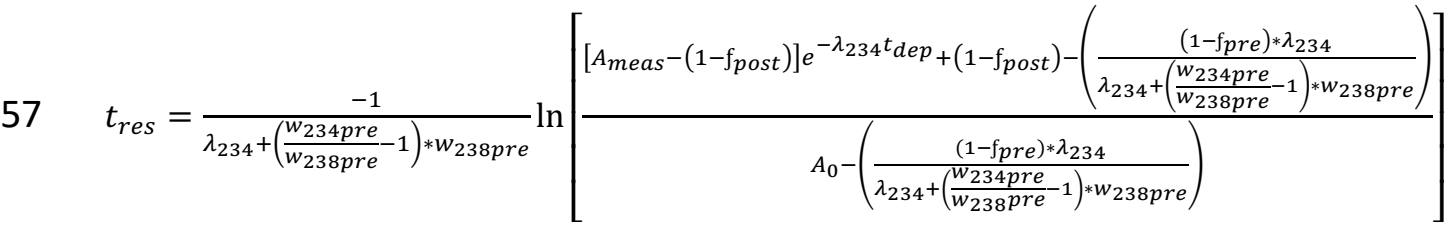

58 where $f_{\text {pre }}$ and $f_{\text {post }}$ are the recoil loss factors before and after final deposition, $A_{\text {meas }}$ is the measured $59\left({ }^{234} \mathrm{U} /{ }^{238} \mathrm{U}\right)$ activity ratio (unitless), $\mathrm{A}_{0}$ the initial $\left({ }^{234} \mathrm{U} /{ }^{238} \mathrm{U}\right)$ activity ratio, i.e. prior to comminution 60 (unitless), $\lambda_{234}$ the ${ }^{234} \mathrm{U}$ decay constant (in $\mathrm{yr}^{-1}$ ), and $t_{\text {dep }}$ the deposition age (in years), as derived from 61 the age-depth model. The recoil loss factors $f_{\text {pre }}$ and $f_{\text {post }}$ are a function of the grain surface area and 62 are defined as follows (Kigoshi, 1971; Maher et al., 2006):

$63 f=\frac{1}{4} L S \rho$

64 with $L$ is the recoil length of ${ }^{234} \mathrm{Th}$ (in $\mathrm{m}$ ), $\rho$ the density of the sediment (in $\mathrm{g} / \mathrm{m}^{3}$ ), and $\mathrm{S}$ the surface area of the sediment $\left(\mathrm{m}^{2} / \mathrm{g}\right)$. We use a Monte Carlo simulation $(10,000$ simulations) with input variables presented in Table S3. Considerations about site-specific input variables $\left(\mathrm{A}_{0}, f_{\text {pre }}, f_{\text {post }}, \mathrm{S}\right.$, $\left.W_{238 p r e} W_{238 p o s t}\right)$ are provided below, all other variables are taken from the literature (Table S2). Uranium-234/ ${ }^{238} \mathrm{U}$ activity ratios of bedrock sampled in the Thirlmere catchment that deviate from expected secular equilibrium are attributed to subareal weathering (for outcrop samples) and to mineral coatings, secondary sandstone cement and/or deep weathering fractures (cf. main text). We relax the assumption of an initial bedrock activity ratio of 1 in our palaeo-sediment residence time calculations by randomly choosing $A_{0}$ between 1 and 1.03 in our Monte-Carlo simulations, with $A_{0}=$ 1.03 as inferred from $\left({ }^{234} \mathrm{U} /{ }^{238} \mathrm{U}\right)$ activity ratio inferred from Hawkesbury sandstone at $21 \mathrm{~m}$ bedrock depth.

Preferential leaching of ${ }^{234} \mathrm{U}$ before and/or after deposition can yield lower $\left({ }^{234} \mathrm{U} /{ }^{238} \mathrm{U}\right)$ activity ratios that are not related to recoil induced loss of ${ }^{234} \mathrm{Th}$. Maher et al. (2004) inferred that the amount of preferential leaching of ${ }^{234} \mathrm{U}$ can be approximate by $w_{238} \approx 0.1 \mathrm{Age}^{-1}$. We herein follow a conservative approach suggested by Francke et al. (2020) by using lowest estimated palaeo-sediment residence times (to maximise $w_{238}$ ) to infer the detrital matter's age, and we use the equation of Maher et al. (2004) to calculate $w_{238 p r e}$ and $w_{238 p o s t}($ Table S2). The impact of different scenarios of pre- and postdepositional preferential leaching is presented in Fig. S2.

82 Loss of ${ }^{234} \mathrm{Th}$ by recoil might be reduced after final deposition in densely compacted depositional 83 archives due to (a) grain to grain recoil, (b) secondary matter (such as organic matter, carbonates) or pore fluid to grain recoil and/or (c) adsorption to mineral surfaces or coatings (Dosseto and Schaller, 
This manuscript is a non-peer reviewed EarthArXiv pre-print. A DOI for the peer-reviewed version will be provided once the manuscript has been accepted. We encourage feedback to the authors.

2016; Priestley et al., 2018). A previous study has demonstrated that considerations about reduced loss of ${ }^{234} \mathrm{Th}$ by recoil after final deposition has no major impact on modelled palaeo-sediment residence in depositional sediments younger than the Late Glacial (Francke et al., 2019). This is also supported by different scenarios for tested for $f_{\text {post }}$ in this study, where Late Glacial to Holocene sediments how palaeo-sediment residences within error of each other in depended of chosen values for $f_{\text {post }}$ (Fig. S2). Not accounting for reduced loss of ${ }^{234}$ Th by recoil after final deposition however leads to unrealistically low and negative palaeo-sediment residences times in the sediments of the last glacial/interglacial complex. A precise estimate of recoil loss of ${ }^{234} \mathrm{Th}$ after final deposition remains challenging and could probably only obtained by detailed mass-balancing between recorded $\left({ }^{234} \mathrm{U} /{ }^{238} \mathrm{U}\right)$ activity ratios of detrital matter, secondary matter (such as organic matter or secondary minerals), and pore waters. Different considerations for $f_{\text {post }}$ have however no direct impact on recorded palaeo-sediment residence time variability and amplitude across the sediments of the last glacial/interglacial complex (Fig. S2). Interpretations about the catchment's response to environmental forcing for the time interval between 139 and 103 ka are therefore not affected. Uncertainties about $f_{\text {post }}$ however hamper a direct comparison of absolute palaeo-sediment residence times for the last versus the current glacial/interglacial complex, a comparison which is therefore not attempt in this study. We find that $f_{\text {post }}=0.25^{*} f_{\text {pre }}$ yields reasonable palaeo-sediment residence times for the last glacial/interglacial complex.

There is a moderately strong negative relationship between estimated external surface area and OM content $\left(R^{2}=0.5\right.$, not shown), and samples from peat or organic silty clay generally yield zero micropore areas (Fig. S1). This is probably explained by organic matter (OM) coating of detrital grains since oxidation of OM rich sediments is frequently incomplete (Mikutta et al., 2005). Incomplete removal of OM during applied sequential leaching has however no impact on recorded $\left({ }^{234} \mathrm{U} /{ }^{238} \mathrm{U}\right)$ activity ratios, since uranium is thought to be comprehensively leached from remaining OM (Francke et al., 2020). Previous studies have however show that the detrital matter's micro to mesopores surface area can be reduced by occluding OM (Kaiser and Guggenberger, 2003). We therefore conclude that samples with zero micropore area are significantly affect by clogging of micro- and mesopores. We consequently relax the assumption of very low external surface area in OM rich deposits and choose $S$ between $28 \mathrm{~m}^{2} / \mathrm{g}$ and $66 \mathrm{~m}^{2} / \mathrm{g}$ for palaeo-sediment time calculations, i.e. within the range of values recorded in silty clay and/or clayey sand. 
This manuscript is a non-peer reviewed EarthArXiv pre-print. A DOI for the peer-reviewed version will be provided once the manuscript has been accepted. We encourage feedback to the authors.

\section{Tables}

116 Table 1: Rock standards and blanks analysed along trace metal samples.

\begin{tabular}{|c|c|c|c|c|c|}
\hline & $\begin{array}{c}\mathbf{U} \\
\left(\mathrm{ppm}^{*} / \mathrm{pg}^{* *}\right)\end{array}$ & $\begin{array}{c}\mathbf{U} \mathbf{2 \sigma} \\
\left(\mathrm{ppm}^{*} / \mathrm{pg}^{* *}\right)\end{array}$ & $\left({ }^{234} U /{ }^{238} U\right)$ & $\left({ }^{234} U /{ }^{238} U\right) 2 \sigma$ & Comment \\
\hline BCR-2 & 1.75 & 0.01 & 0.997 & 0.005 & Neptune \\
\hline BCR-2 & 1.01 & 0.001 & 0.998 & 0.002 & Neptune \\
\hline BCR-2 & 0.96 & 0.002 & 0.998 & 0.003 & Neptune \\
\hline BCR-2 & 1.26 & 0.10 & & & Q-ICAP \\
\hline QLO-01a & 1.42 & 0.05 & & & Q-ICAP \\
\hline QLO-01a & 1.61 & 0.01 & 0.999 & 0.004 & Neptune \\
\hline QLO-01a & 1.08 & 0.002 & 1.001 & 0.003 & Neptune \\
\hline QLO-01a & 0.83 & 0.001 & 1.003 & 0.003 & Neptune \\
\hline Blank & 196.69 & 1.92 & 1.004 & 0.039 & Neptune \\
\hline Blank & 144.5 & 1.4 & 1.002 & 0.022 & Neptune \\
\hline Blank & 242.9 & 1.3 & 0.902 & 0.016 & Neptune \\
\hline Blank & 176.0 & 0.6 & 1.033 & 0.020 & Neptune \\
\hline Blank & 7.7 & 26.7 & & & Q-ICAP \\
\hline Blank & 21.0 & 15.3 & & & Q-ICAP \\
\hline $\mathrm{LC} 2-40 \mathrm{~cm}^{+}$ & 0.95 & 0.10 & 0.773 & 0.003 & \\
\hline $\mathrm{LC} 2-180 \mathrm{~cm}^{+}$ & 1.19 & 0.003 & 0.811 & 0.003 & \\
\hline $\mathrm{LC} 2-302 \mathrm{~cm}^{+}$ & 1.46 & 0.01 & 0.706 & 0.005 & \\
\hline $\mathrm{LC} 2-410 \mathrm{~cm}^{+}$ & 2.02 & 0.01 & 0.811 & 0.005 & \\
\hline $\mathrm{LC} 2-410 \mathrm{~cm}^{+}$ & 1.83 & 0.01 & 0.819 & 0.004 & \\
\hline WBRC1-22.5cm $\mathrm{cm}^{+}$ & 1.90 & 0.34 & 0.886 & 0.002 & \\
\hline
\end{tabular}

$117{ }^{*}$ for rock standards and replicates, ${ }^{* *}$ for blanks, ${ }^{+}$replicates

119 Table 2: Input parameter for palaeo-sediment residence time modelling as shown in the main text.

\begin{tabular}{lll} 
Parameter & Value & Source \\
\hline$A_{\text {meas }}$ & Analysed & measured \\
$A_{0}$ & $1-1.03$ & Between secular equilibrium and \\
& & Hawkesbury Sandstone at 21m depth \\
\hline
\end{tabular}


This manuscript is a non-peer reviewed EarthArXiv pre-print. A DOI for the peer-reviewed version will be provided once the manuscript has been accepted. We encourage feedback to the authors.

\begin{tabular}{|c|c|c|}
\hline$f_{\text {pre }}$ & Calculated & Eq. (2) \\
\hline$f_{\text {post }}$ & Calculated & $f_{\text {pre }} * 0.25$ \\
\hline$t_{\text {dep }}$ & Calculated & Chronology of Forbes et al. (2021) \\
\hline$\lambda_{234}$ & $2.826 \times 10^{-6} \mathrm{yr}^{-1}$ & \\
\hline $\mathrm{L}$ & $30 \mathrm{~nm}$ & Dosseto and Schaller (2016) \\
\hline$\rho$ & $2.6 \times 10^{-6} \mathrm{~g} / \mathrm{cm}^{3}$ & \\
\hline$S$ & $28 \mathrm{~m}^{2} / \mathrm{g}$ to $66 \mathrm{~m}^{2} / \mathrm{g}$ & measured \\
\hline $\mathrm{W}_{234 \mathrm{pre}} / \mathrm{W}_{238 \mathrm{pre}}$ & $1.2 \pm 0.2$ & (Dosseto et al., 2006; Dosseto et al., 2014) \\
\hline W238pre & $1.11 \times 10^{-6} \mathrm{yr}^{-1}$ & Calculated after Maher et al., 2004 \\
\hline$W_{234 p o s t} / W_{238 p o s t}$ & $1.2 \pm 0.2$ & Dosseto et al. $(2006,2014)$ \\
\hline$W_{238 p o s t}$ & $6.67 \times 10^{-7} \mathrm{yr}^{-1}$ & Calculated after Maher et al. (2004) \\
\hline
\end{tabular}

\section{Figure Captions}

122 Fig. S1: Lithology and radiocarbon and luminescence data of core LC2. All data presented were previously published by Forbes et al. (2021).

Fig. S2: Palaeo-sediment residence times modelled using 10,000 MonteCarlo Simulations with difference leaching parameters $w_{238}$ and $w_{234} / w_{238}$. The experiments were carried out to test the impact of preferential leaching of ${ }^{234} \mathrm{U}$ on estimated palaeo-sediment residence times. See

\section{Bibliography}

DePaolo, D.J., Maher, K., Christensen, J.N., McManus, J., 2006. Sediment transport time measured with U-series isotopes: Results from ODP North Atlantic drift site 984. Earth and Planetary Science Letters, 248(1-2): 394-410.

Dosseto, A., Bourdon, B., Gaillardet, J., Mauricebourgoin, L., Allegre, C., 2006. Weathering and transport of sediments in the Bolivian Andes: Time constraints from uranium-series isotopes. Earth and Planetary Science Letters, 248(3-4): 759-771. 
This manuscript is a non-peer reviewed EarthArXiv pre-print. A DOI for the peer-reviewed version will be provided once the manuscript has been accepted. We encourage feedback to the authors.

Dosseto, A., Schaller, M., 2016. The erosion response to Quaternary climate change quantified using uranium isotopes and in situ-produced cosmogenic nuclides. Earth-Science Reviews, 155: 6081.

Forbes, M. et al., 2021. Comparing interglacials in eastern Australia: A multi-proxy investigation of a new sedimentary record. Quaternary Science Reviews, 252.

Francke, A., Dosseto, A., Just, J., Wagner, B., Jones, B.G., 2020. Assessment of the controls on $(234 \mathrm{U} / 238 \mathrm{U})$ activity ratios recorded in detrital lacustrine sediments. Chemical Geology: 119698.

Francke, A. et al., 2019. Sediment residence time reveals Holocene shift from climatic to vegetation control on catchment erosion in the Balkans. Global and Planetary Change, 177: 186-200.

Halsey, G., 1948. Physical Adsorption on Non-Uniform Surfaces. The Journal of Chemical Physics, 16(10): 931-937.

Kaiser, K., Guggenberger, G., 2003. Mineral surfaces and soil organic matter. European Journal of Soil Science, 54(2): 219-236.

Kigoshi, K., 1971. Alpha-recoil Thorium-234: Dissolution into water and the uranium-234/uranium238 disequilibrium in nature. Science, 173(3991): 47.

Maher, K., DePaolo, D.J., Lin, J.C.-F., 2004. Rates of silicate dissolution in deep-sea sediment: In situ measurement using $234 \mathrm{U} / 238 \mathrm{U}$ of pore fluids. Geochimica et Cosmochimica Acta, 68(22): 4629-4648.

Maher, K., Steefel, C.I., DePaolo, D.J., Viani, B.E., 2006. The mineral dissolution rate conundrum: Insights from reactive transport modeling of $U$ isotopes and pore fluid chemistry in marine sediments. Geochimica et Cosmochimica Acta, 70(2): 337-363.

Mikutta, R., Kleber, M., Kaiser, K., Jahn, R., 2005. Review: organic matter removal from soils using hydrogen peroxide, sodium hypochlorite, and disodium peroxodisulfate. Soil Science Society of America Journal, 69(1): 120-135.

Priestley, S.C. et al., 2018. Use of U-isotopes in exploring groundwater flow and inter-aquifer leakage in the south-western margin of the Great Artesian Basin and Arckaringa Basin, central Australia. Applied Geochemistry, 98: 331-344.

Sims, K.W.W. et al., 2008. An Inter-Laboratory Assessment of the Thorium Isotopic Composition of Synthetic and Rock Reference Materials. Geostandards and Geoanalytical Research, 32(1): 6591. 


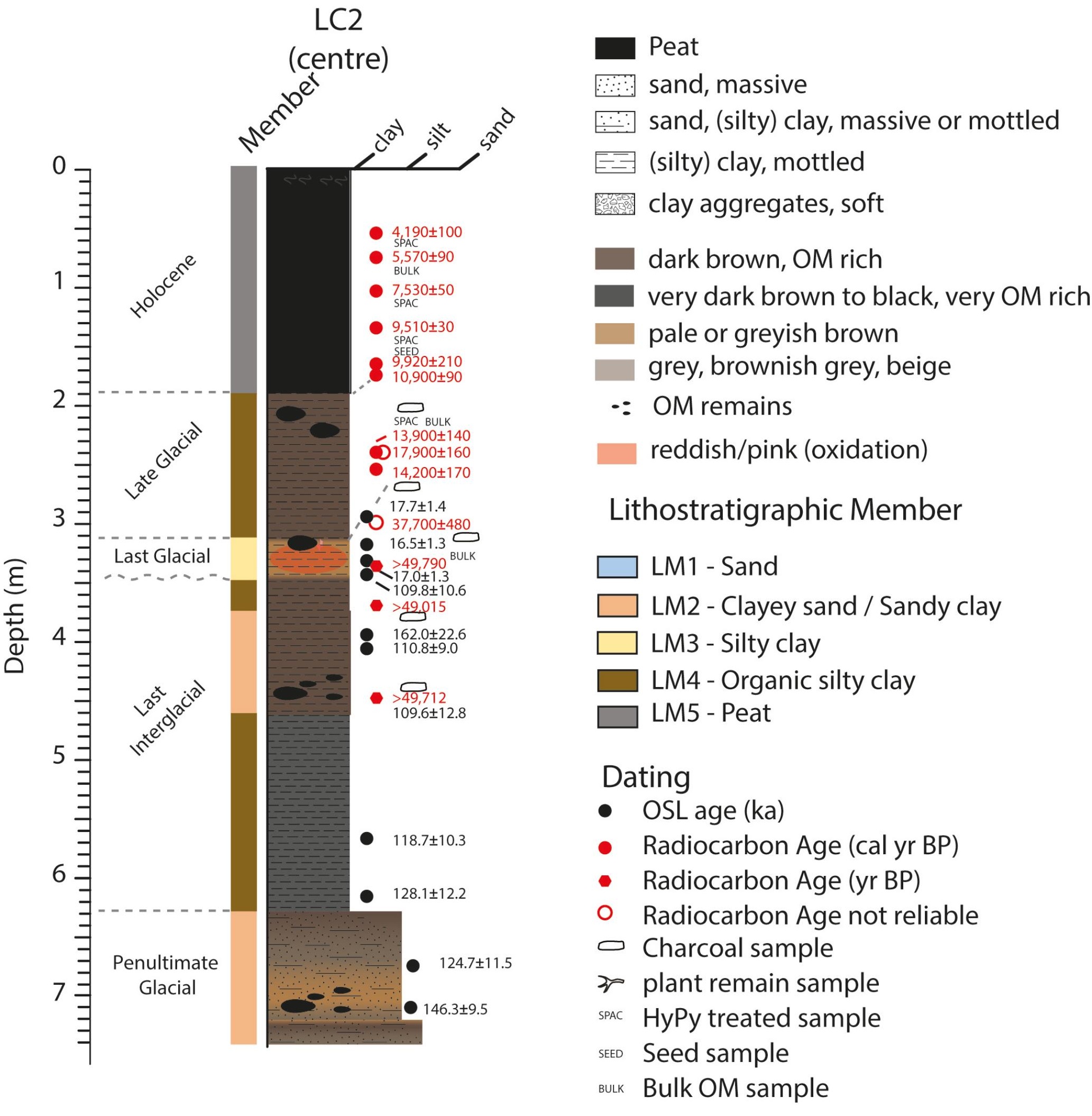



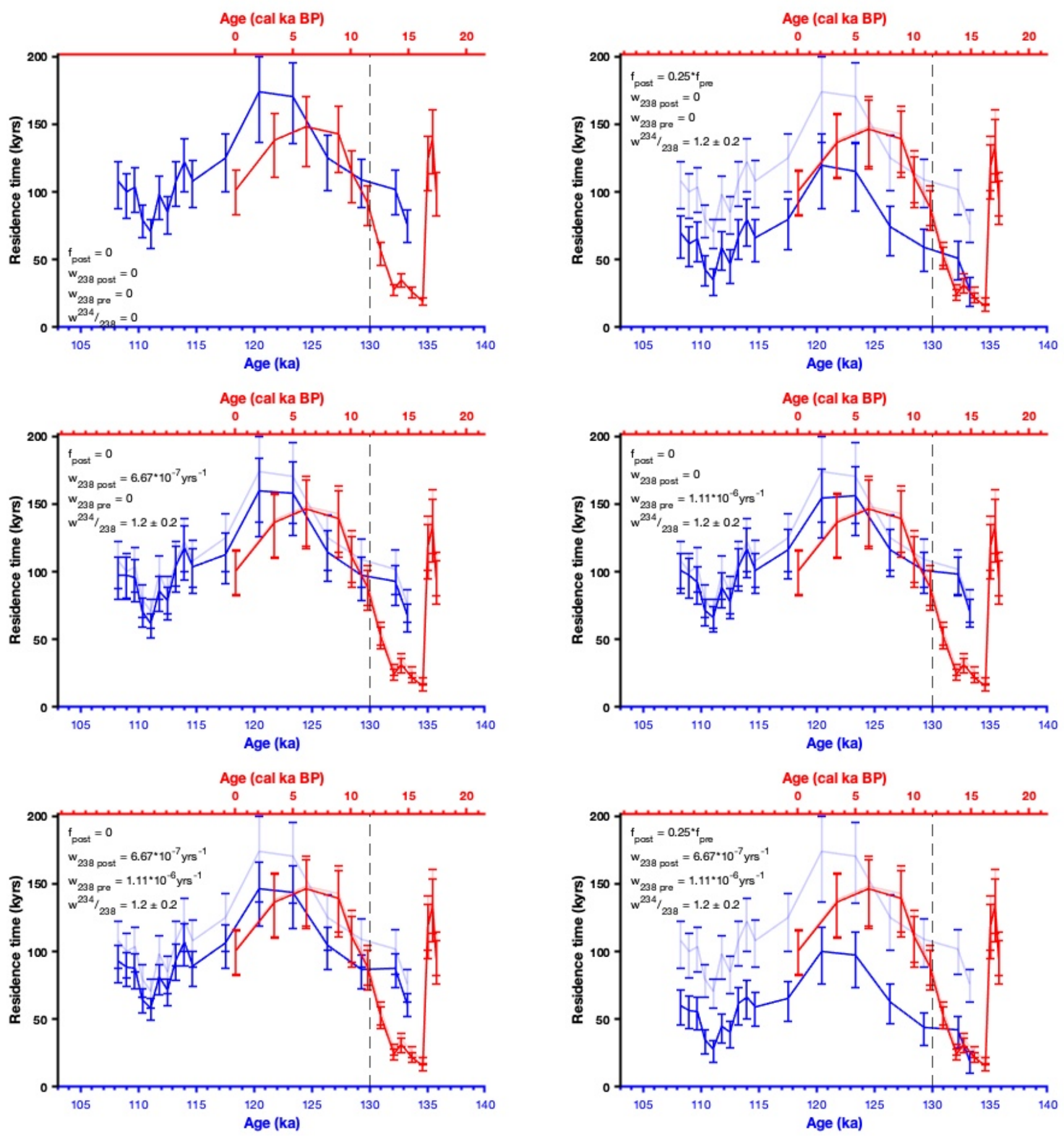